NAT'L INST OF STAND \& TECH

Al1306 243046

NIST

PUBLICATIONS

\title{
Survey on the Implementation of ISO/IEC Guide 25 by National Laboratory Accreditation Programs
}

Maureen Breitenberg

U.S. DEPARTMENT OF COMMERCE Technology Administration National Institute of Standards and Technology

Gaithersburg, MD 20899 



\section{Survey on the Implementation of ISO/IEC Guide 25 by National Laboratory Accreditation Programs}

Maureen Breitenberg

U.S. DEPARTMENT OF COMMERCE Technology Administration

National Institute of Standards

and Technology

Gaithersburg, MD 20899

July 1994

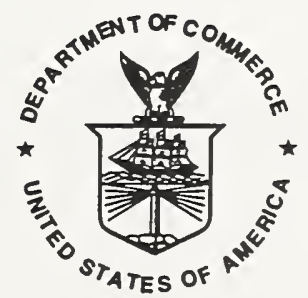

U.S. DEPARTMENT OF COMMERCE Ronald H. Brown, Secretary

TECHNOLOGY ADMINISTRATION

Mary L. Good, Under Secretary for Technology

NATIONAL INSTITUTE OF STANDARDS

AND TECHNOLOGY

Aratl Prabhakar, Dlrector 



\section{ABSTRACT}

Laboratory accreditation has taken on increased significance worldwide as international acceptance of national laboratory calibrations and test results has assumed greater importance in the reduction of technical barriers to trade. Creating confidence in the competence of laboratories which perform required testing and calibrations is vital for securing global acceptance of the results of such testing and calibration -- increasingly a requirement for international trade.

The International Organization for Standardization/International Electrotechnical Commission (ISO/IEC) Guide 25, General requirements for the competence of calibration and testing laboratories, has been used by many laboratory accreditation programs worldwide to establish accreditation requirements designed to promote confidence in the calibrations and testing results of laboratories which conform to the guide's requirements. Standards and guides published by ISO and IEC must be revised or reaffirmed at least once every five years. ISO/IEC Guide 25, which was last revised in 1990, is scheduled for revision/reaffirmation in 1995.

National delegations to the International Laboratory Accreditation Conference (ILAC), an international conference of national organizations interested in laboratory accreditation, were surveyed to collect information on the implementation and supplementation of the requirements of ISO/IEC Guide 25 within the context of their countries' laboratory accreditation programs. This report summarizes the results of that survey. Such information can be useful in revising the guide. The report also includes a bibliographic list of publications concerned with ISO/IEC Guide 25 implementation complied from the information submitted by the national delegations. These publications provide more detailed information on the nature and content of each program's supplementary guidance.

Improving the contents of ISO/IEC Guide 25 can serve to increase the use of this guide by U.S. and non-U.S. accreditation programs and provide a mechanism for improved recognition.

Key Words: accreditation; CASCO; ILAC; international standards; ISO/IEC Guide 25; laboratory accreditation; mutual recognition schemes; testing 



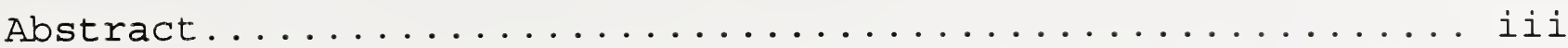

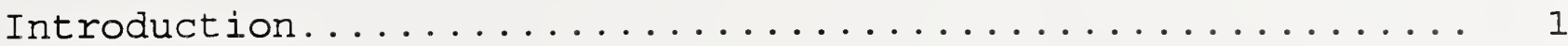

History and Status of ISO/IEC Guide $25 \ldots \ldots \ldots \ldots \ldots$

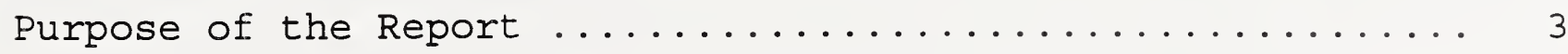

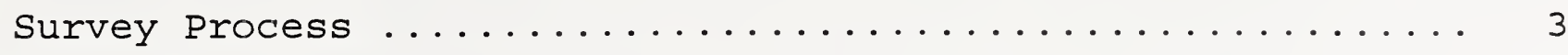

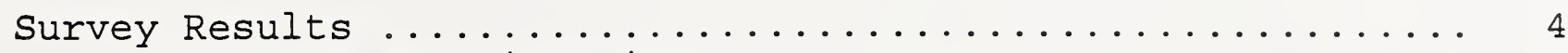

Completed Questionnaires ......................... 4

Programs with Guidance or Instructions that Interpret/ Amplify ISO/IEC Guide 25 Requirements ............. 5

Sections of ISO/IEC Guide 25 with the Most Additional

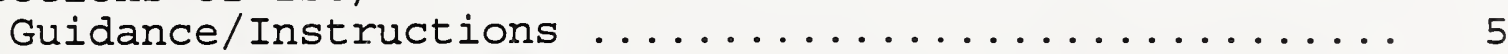

Fields of Testing Covered by the Programs .......... 6

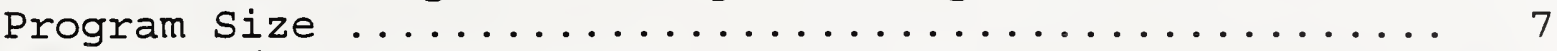

Mandatory/Voluntary status of Programs ............. 7

References to ISO/IEC Guide 25 in Law or Regulation .. 8

Published List of Accreditation Requirements and Availability in English ................... 8

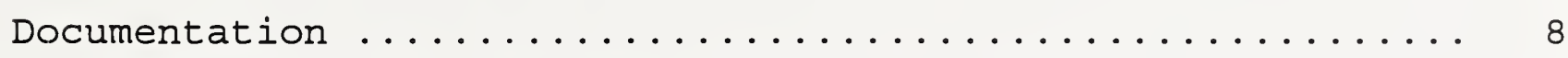

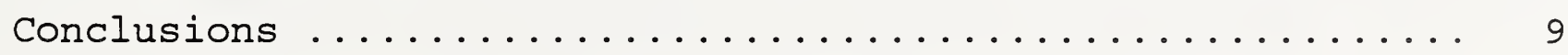

Appendix I -- ILAC Committee 3 Working Group 7 Active

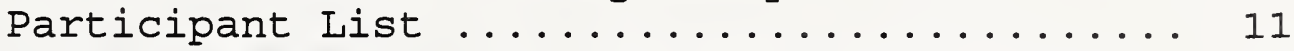

Appendix II - - List of Heads of ILAC National Delegations .. 13

Appendix III - ISO/IEC Guide 25 Questionnaire ........... 17

Appendix IV - - List of U.S. Accreditation Requirements

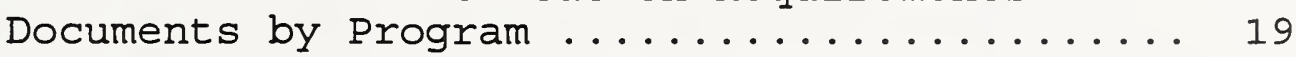

Appendix V - - List of Accreditation Requirements Documents by Country/Program ........... 21

Appendix VI - - List of Laboratory Accreditation Programs Included in the Analysis ............... 27

Appendix VII - Breakdown of U.S. and Non-U.S. Responses Regarding Additional Guidance/Instructions . . 35

Appendix VIII - ISO/IEC Guide 25 Questionnaire U.S. Survey Summary ................ 37

Appendix IX - - ISO/IEC Guide 25 Questionnaire - Non-U.S.

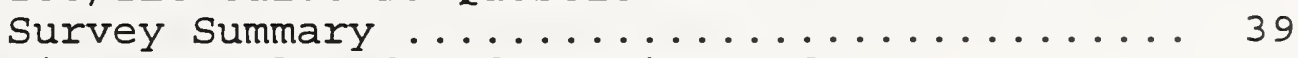

Appendix X - - List of Related Information and Publications Available from NIST 



\section{INTRODUCTION}

Laboratory accreditation has assumed increased significance worldwide as international acceptance of national testing and calibration results has taken on greater importance in the reduction of technical barriers to trade. Creating confidence in the competence of calibration and testing laboratories is vital for securing global acceptance of testing and calibration results which can lead to reduction in such potential trade barriers. Building such confidence can be facilitated through the international adoption and use of harmonized laboratory accreditation requirements, such as the International Organization for Standardization and the International Electrotechnical Commission (ISO/IEC) Guide 25, General requirements for the competence of calibration and testing laboratories.

ISO/IEC Guide 25 has been used by may laboratory accreditation programs worldwide to establish accreditation requirements. These requirements are designed to promote confidence in the calibrations and testing results of laboratories demonstrating conformity to the guide. Standards and guides published by Iso and IEC are required to be revised or reaffirmed at least once every five years. ISO/IEC Guide 25, which was last revised in 1990, is scheduled for revision/ reaffirmation in 1995. Improving the scope and requirements of ISO/IEC Guide 25 during the upcoming revision process can increase the use of this guide by U.S. and non-U.S. accreditation programs and further enhance opportunities for international cooperation and mutual recognition.

\section{HISTORY AND STATUS OF ISO/IEC GUIDE 25}

The history of ISO/IEC Guide 25 began in 1977 when the International Laboratory Accreditation Conference (ILAC) was established in Copenhagen. ILAC, an informal forum of national delegations interested in laboratory accreditation, has as one of its objectives the definition and advancement of principles and practices of laboratory accreditation through consensus agreement. ILAC has been responsible for developing drafts of all three editions of Guide 25. Because ILAC does not itself publish international standards or guides, these drafts have been turned over to the International Organization for standardization (ISO) and the International Electrotechnical Commission (IEC) for review, approval and publication as ISO/IEC guides ${ }^{1}$.

1/ The first edition of Guide 25 was published by ISO/CERTICO - the predecessor of the Iso council committee on conformity assessment (CASCO). Both ISO and IEC have jointly approved and issued revisions of Guide 25 since the 1982 edition. 
Guide 25 was first published in 1978 as Guidelines for assessing the technical competence of testing laboratories. Its primary objective was to establish criteria for evaluating the technical competence of laboratories. The guide went beyond the traditional approach of looking at only the technical adequacy of the test methods, calibration procedures, and statistical controls used. It also established requirements for technical and administrative practices to ensure laboratory competence and provide continuity and consistency within a laboratory's operations.

In the 1982 edition of the guide, the concept of quality system was introduced and the guide's requirements were expanded, though the format and substance of the guide remained basically the same as the first edition.

The scope of the 1990 edition of ISO/IEC Guide 25 is even more comprehensive than the 1982 edition. The 1990 edition of the guide was expanded to specifically include calibration laboratories. The guide's requirements were also noticeably broadened in the areas of test results presentation and the development and maintenance of a quality manual. In addition, most of the requirements of ISO 9002, Quality systems - Model for quality assurance in production and installation, which were applicable to laboratories were incorporated into the guide to eliminate the need for laboratories to prove compliance with both the guide and ISO 9002 .

ISO/IEC Guide $25^{\prime}$ s requirements now cover:

- Organization and Management

- Quality System Audit and Review, including: establishing and maintaining a quality manual; the conduct of internal audits; taking corrective action; and checking of the quality of testing/calibration results

- Personnel, including: establishing and documenting staff education, training and experience

- Accommodation and Environment, including the adequacy of laboratory facilities and environmental conditions

- Equipment and Reference Materials, including the availability, calibration, and maintenance and labeling of equipment (including reference materials)

- Measurement Traceability and Calibration

- Calibration and Test Methods, including: calibration instructions; test method requirements; test method documentation; and test method availability

- Handling of Calibration and Test Items

- Records

- Certificates and Reports, including: content/format; modifications; and client notification 
- Subcontracting; including types of work eligible for subcontracting; subcontractor competency; and client notification

- Outside Support Services and Supplies

- Complaints; including documentation of policy and procedures for resolution of complaints; and actions taken in response to complaints

Since it was first published in 1978, ISO/IEC Guide 25 increasingly has become the internationally accepted standard for assessing the competence of calibration and testing laboratories. IsO/IEC Guide 25 has been used by U.S. and non-U.S. laboratory accreditation programs to establish their accreditation requirements. Although (as indicated by the list above) current requirements of the guide are quite comprehensive, a number of laboratory accreditation bodies which use ISO/IEC Guide 25 as the basis for their accreditation requirements have felt the need to include additional requirements and clarifications within their accreditation programs beyond those currently contained in the guide.

Standards and guides published by ISO and IEC, including ISO/IEC Guide 25, are required to be revised or reaffirmed at least once every five years. ISO/IEC Guide 25, last revised in 1990, is scheduled for revision/reaffirmation in 1995. Since ILAC is currently in the process of reviewing the need for revisions to the guide, information on areas where laboratory accreditation bodies have felt the need to supplement or clarify the guide's requirements can be useful in the revision process.

\section{PURPOSE OF THE REPORT}

Each of the thirty-four national delegations to ILAC was surveyed to obtain information on the implementation and supplementation of the requirements of ISO/IEC Guide 25 within the context of their country's laboratory accreditation programs. This report summarizes the results of that survey. Such information should be useful in determining where revisions or clarifications are needed in the 1990 edition of ISO/IEC Guide 25 to further its usage and increase harmonization of laboratory accreditation requirements internationally.

\section{SURVEY PROCESS}

A draft questionnaire on the implementation of ISO/IEC Guide 25 within individual laboratory accreditation programs was developed 
and circulated to participants in ILAC Committee 3 Working Group $7^{2}$ for suggested revisions. Based on the suggestions received, the questionnaire was revised. The revised questionnaire was then mailed to the heads of the ILAC delegations (listed in Appendix II) for completion by appropriate parties within their countries. A copy of the questionnaire is included in Appendix III.

The questionnaire was designed to collect information on: (1) whether U.S. and non-U.S. laboratory accreditation programs had incorporated the requirements of ISO/IEC Guide 25 into their program requirements; and (2) what (if any) supplementation or clarification of the requirements of the guide was also included. Delegation leaders were asked to provide a completed questionnaire for each of their national accreditation programs. Responses were voluntary and 38 questionnaires were completed and returned.

Survey recipients were also asked to provide a list of relevant publications. A bibliographic list of such publications was complied from the information submitted and is included in Appendices IV and $V$ of this report. The publications listed in Appendices IV and V provide more detailed information on the nature and content of each program's supplementary guidance.

For each accreditation program, the following information was requested:

- Fields of testing covered by the program;

- Number of laboratories accredited by the program;

- Voluntary or mandatory nature of the program;

- References to ISO/IEC Guide 25 in law or regulation;

- Availability of a published list of accreditation requirements and whether such documents were available in English;

- Consistency of program requirements with ISO/IEC Guide 25 ;

- Availability of guidance/instructions that interprets/amplifies ISO/IEC Guide 25 requirements and whether such guidance/ instructions varied by test field; and

- Sections of ISO/IEC Guide 25 requiring such additional guidance/instruction.

\section{SURVEY RESULTS}

Completed Questionnaires:

The results from 37 completed questionnaires were used in this study - - 31 from non-U.S. laboratory accreditation programs and six from U.S. programs. A list of the 37 programs in 26 countries for which responses were received is included in Appendix VI.

2/ Committee 3 is concerned with Laboratory Management and operation. It undertakes studies of the management and operation of testing and calibration laboratories as these relate to laboratory accreditation. Working Group (WG) 7 of Committee 3 was assigned responsibility for developing a questionnaire to collect information and bibliographic references of publications on the implementation of ISO/IEC Guide 25. A list of active participants on WG 7 is included in Appendix I. 
One non-U.S. response was not included because the program was being terminated. Eight U.S. responses were received on six U.S. programs. Two responses were received from different U.S. federal government agencies on the U.S. Department of Labor's Nationally Recognized Testing Laboratory (NRTL) program, which contained different information. Information relevant to the laboratory accreditation portion of the program was used. Two responses were also received from the National Institute of standards and Technology's (NIST's) National Voluntary Laboratory Accreditation Program (NVLAP). The response from the head of NVLAP was used.

Programs with Guidance or Instructions that Interpret/Amplify ISO/IEC Guide 25 Reguirements:

Twenty-seven programs had guidance that interpreted or amplified the requirements listed in ISO/IEC Guide 25, while ten did not.

For 14 of the programs with such guidance, that guidance varied by test field.

Nearly all programs (which responded or responded appropriately to the question on which version of Guide 25 was in use) were using the 1990 version. Only two programs were using the 1982 version. The responses therefore primarily refect supplementation developed for the 1990 version.

Sections of ISO/IEC Guide 25 with the Most Additional Guidance/ Instructions

The three items that appeared most frequently on the questionnaires as requiring supplementation were: (1) System Audit/Review - 23 Responses; (2) Traceability and Calibration - 21 Responses; and (3) Certificates - 19 Responses. Because of the frequency with which laboratory accreditation programs supplemented or clarified these items in their documentation, these areas should be carefully reviewed during the revision process.

Under system. Audit/Review, the most frequently named sub-items requiring supplementation were: the quality manual and quality system documentation (18 responses) and internal audits (15 responses). Under Traceability and Calibration, the most frequently named sub-items requiring supplementation were: standard reference materials (15 responses) and equipment calibration (13 responses). Under Certificates, the most frequently named items requiring supplementation were: content and format of the certificate ( 13 responses) and modifications to the certificate (10 responses).

A list of the total number of responses rank ordered by frequency of response is listed below: 


\section{SECTIONS OF GUIDE 25 WITH THE MOST ADDITIONAL GUIDANCE/INSTRUCTIONS}

REOUIREMENT

TOTAL RESPONSES

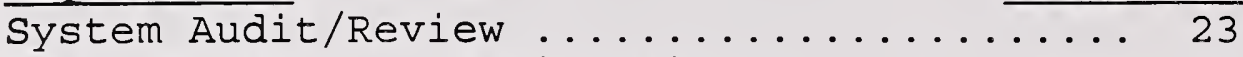

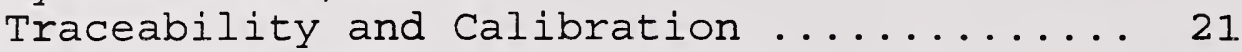

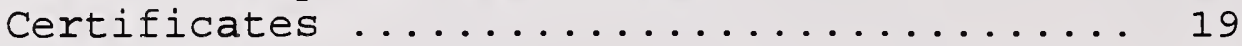

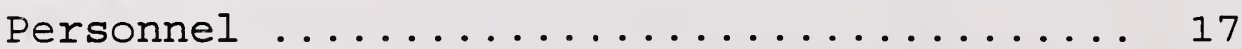

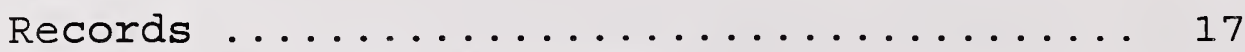

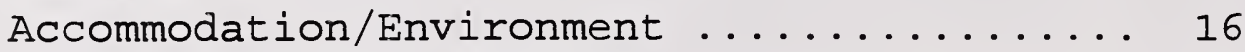

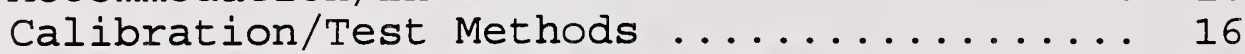

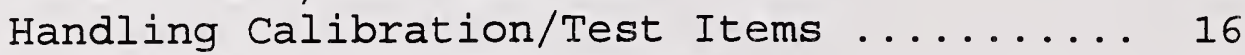

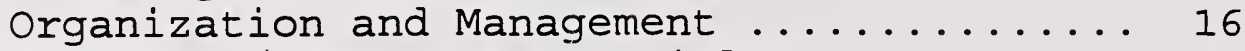

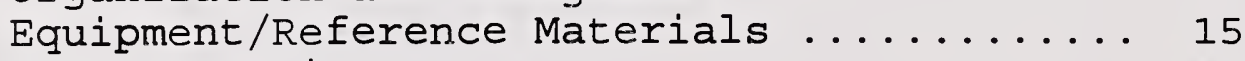

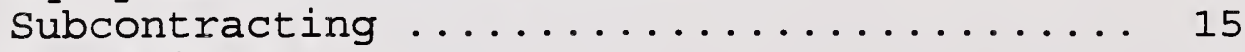

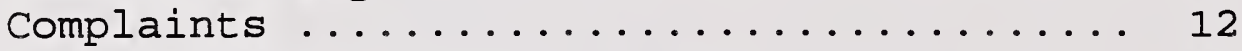

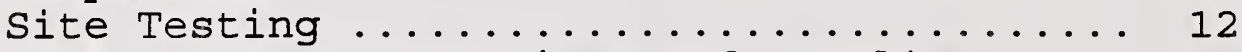

Outside Support Services and Supplies ..... 11

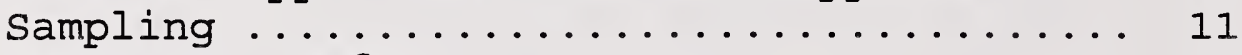

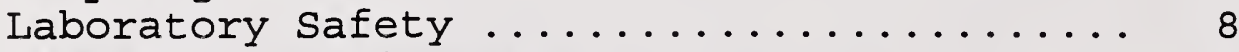

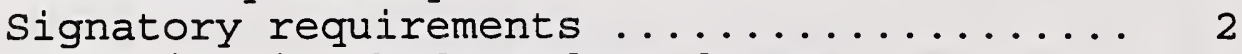

Accreditation body endorsed test reports .. 2

Confidentiality and proprietary rights .... 1

Subcontracting to accredited labs only .... 1

Verification practices ................... 1

Additional requirements for calibration labs 1

A breakout of the U.S. and non-U.S. responses to items and subitems in ISO/IEC Guide 25 as well as additional items not included in the guide which require supplementation are listed in Appendix VII.

Fields of Testing Covered by the Programs:

Mechanical (30 responses), chemical (29 responses), and electrical testing ( 29 responses) were the most common testing fields covered by the 37 programs. The breakdown below, however, indicates that the scope of many of the accreditation programs included a broad range of testing fields.

It is interesting to note that while some laboratory accreditation programs categorized the scope of their activities by fields of testing, other programs were only able to define their scope by the product areas covered. Such differences in approach to defining program scope can create difficulties in comparing programs and in creating mutual recognition agreements. A more consistent approach to defining laboratory accreditation program scope might be a useful addition to ISO/IEC Guide 25. 


\begin{tabular}{|c|c|}
\hline $\begin{array}{l}\text { Testing Field } \\
\text { Covered }\end{array}$ & $\begin{array}{l}\text { No. of } \\
\text { Programs }\end{array}$ \\
\hline Biological ......... & .25 \\
\hline 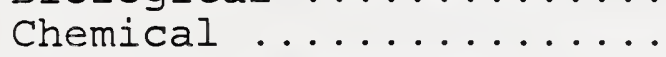 & . 29 \\
\hline Ionizing Radiation ...... & . 17 \\
\hline 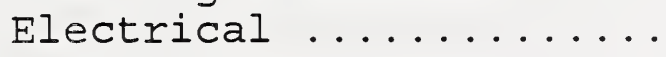 & 29 \\
\hline Mechanical & . 30 \\
\hline Metrology & . 24 \\
\hline Non-destructive & . 22 \\
\hline 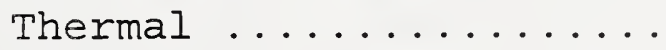 & . 23 \\
\hline Optics \& Photometry ..... & . 20 \\
\hline Acoustic/Vibration & \\
\hline Measurement ... & 21 \\
\hline
\end{tabular}

Other fields also specified by the programs included: gas cylinders ( 1 program); applied physics ( 1 program); wool (2 programs); medical (2 programs); ballistic (1 program); corrosion ( 1 program); EMC (2 programs); environmental ( 3 programs); fire (3 programs); geology ( 1 program); health \& hygiene (1 program); information technology (2 programs); metallurgical (1 program); microbiological ( 3 programs); physical safety sampling ( 1 program); product safety testing ( 2 programs); physico-chemical ( 1 program); fire protection ( 1 program); construction materials ( 3 programs); toys ( 1 program); textiles ( 1 program); food ( 3 program); physical ( 1 program); building techniques ( 1 program); civil engineering ( 1 program); animal health ( 1 program); and electronics and fluid flow ( 1 program).

\section{Program Size:}

The size of the accreditation programs which responded to the questionnaire varied from only one laboratory accredited to over 2300 accredited laboratories. A breakdown by size is included below:

$\begin{array}{rrr}\text { NUMBER OF LABORATORIES ACCREDITED : } \\ 1 \text { to } 10 \text { laboratories: } & 10 \\ 11 \text { to } 50 \text { laboratories: } & 8 \\ 51 \text { to } 100 \text { laboratories: } & 8 \\ 101 \text { to } 200 \text { laboratories: } & 3 \\ 201 \text { to } 500 \text { laboratories: } & 5 \\ 501 \text { to } 1000 \text { laboratories: } & 0 \\ \text { Over } 1000 \text { laboratories: } & 4\end{array}$

Mandatory/Voluntary Status of Programs:

Participation in 30 of the responding accreditation programs was voluntary, while participation in two programs was mandatory for laboratories operating within their scope of activities. Five respondents indicated that participation was either mandatory for some testing fields while voluntary for others or the use of an accredited laboratory was mandatory for testing certain products, but participation in the program was voluntary for the laboratory.

It should be noted that some of the 30 programs which listed themselves as voluntary in the questionnaire may be "quasi- 
mandatory" for certain products or under certain circumstances. For example, the Department of Labor's Nationally Recognized Testing Laboratory (NRTL) program listed itself as voluntary. However, use of an accredited laboratory is mandatory for manufacturers of certain products.

The requirements of the two mandatory programs were both consistent with ISO/IEC Guide 25, though only one program had the guide mentioned in law or regulation. Neither had any guidance that interpreted or amplified the guide's requirements.

Three of the five "sometimes mandatory" programs had supplementary requirements. All three had supplementary guidance/requirements for quality system audit/review area, and two had additional guidance/requirements for personnel, accreditation certificates, subcontracting, calibration and test methods, and the handling of calibration and test items. Supplementary guidance/ requirements for organization and management, accommodation/ environment, equipment/reference materials, traceability and calibration, records, sampling and inspection prior to participation in a certification program were each checked by only one program.

References to ISO/IEC Guide 25 in Law or Regulation:

ISO/IEC Guide 25 was specifically mentioned in the laws or regulations governing 14 of the programs. It was not mentioned for 18 programs. For four programs, it was mentioned in laws or regulations governing bodies other than the laboratory accreditation body, i.e., by some state governments. One program did not respond to the question.

Published List of Accreditation Requirements and Availability in English:

Thirty-four programs had published a list of accreditation requirements, while three had not. Of these, all 34 were consistent with one of the three editions of Guide 25 ; and 29 indicated that they were consistent with the 1990 edition.

\section{DOCUMENTATION}

A list of the documents prepared by the various laboratory accreditation programs is included in Appendices V and VI, many of which are available in English. Several are of particular note and are summarized below.

Documents prepared by Hong Kong's Laboratory Accreditation Scheme (HOKLAS) include guidance on a wide range of specific areas from advertising to the conduct of quality audits. Those prepared by New Zealand's TELARC program contain guidance on developing quality manuals as well as guidance in a number of product specific areas. Singapore's Laboratory Accreditation Scheme (SINGLAS) has developed guidance for a number of testing fields ranging from calibration and measurement to non-destructive testing. Guidance documents prepared by the United Kingdom's NAMAS program are particularly extensive and not only cover specific testing fields and products, but include general guidance on issues ranging from traceability to quality manuals. While other programs have also published 
additional guidance/supplementary requirements, much of that documentation is not available in English.

While guidance contained in some documents may be specific to certain types of testing or laboratories and may not be appropriate for inclusion in ISO/IEC Guide 25, laboratory accreditation bodies should nonetheless be encouraged to share such documentation with other accreditation bodies whose programs include similar types of testing and/or laboratories.

Ideally, representatives from programs (such as those noted above) which have prepared extensive guidance documentation should participate in the revision process. If such representatives can not participate, however, a review of their documentation should be included within the ISO/IEC Guide 25 revision process.

\section{CONCLUSIONS}

Based on the information provided by the survey, it would appear that the revision process should focus particularly on reviewing and clarifying or expanding ISO/IEC Guide 25's requirements for: (1) quality system audit and review; (2) measurement traceability and calibration; and (3) the accreditation certificate. Within these categories, particular attention should be given to requirements for the quality manual and quality system documentation and internal audits; requirements for the use of standard reference materials and equipment calibration; and requirements for the content/format and modification of the accreditation certificate. In addition, consideration should be given to including new requirements for: sampling; site testing; laboratory safety.

Making such changes could improve the scope and contents of ISO/IEC Guide 25 and serve to increase its use by U.S. and non-U.S. accreditation programs - - thus providing a mechanism for improved U.S. and international cooperation and mutual recognition. 


\section{APPENDIX I}

\section{ILAC COMMITTEE 3 WORKING GROUP 7 ACTIVE PARTICIPANT LIST}

Mr. M. ALAAN BRYDEN

General Director

Laboratoire national d'essais - LNE 1, rue Gaston Boissier

PARIS

FRANCE 75015

Mr. JOHN DONALDSON

Manager

Standards Code and Information Program

National Institute of Standards and Technology (NIST)

Building 101, Room A629

Gaithersburg, MD 20899

Mr. M. GILLES DUPRIEZ

Engineer

Reseau national d'essais - RNE

52 , rue Madame

PARIS

FRANCE 75006

Dr. THOMAS FACKLAM

Director

DATECH

Stresemannallee 19

FRANKFURT, HESSE

GERMANY D-6000

Mr. MIEW LIM CHIN

Head of Accreditation

SIRIM/SAMM

P.O. BOX 7035

KUALA LUMPUR SHAH ALAM

MALAYSIA 40911

Mr. JAVIER DOMINGUEZ

Advisor

Red Espanola de Laboratorios de Ensayo - RELE

Avda. de Concha Espina, 65, 2.0

MADRID

SPAIN 28016
Mr. HARVEY E. SCHOCK Jr.

Consultant

Product Assurances

30 Oak Ridge Drive

HADDONFIELD, NJ 08033-3507

NIGEL N. L. JOU

Industrial Technology Research Institute

321 Section 2

Hsin-Chu Taiwan

Republic of China 30042 
12 


\section{LIST OF HEADS OF ILAC NATIONAL DELEGATIONS ${ }^{3}$}

MR. JOHN A. GILMOUR

CHIEF EXECUTIVE

NATIONAL ASSOCIATION OF TESTING

AUTHORITIES, AUSTRALIA - NATA

7 LEEDS STREET

RHODES, NSW

AUSTRALIA 2138

MS. REGINA COELI MENDES

FISICA

INMETRO

AV. NOSSA SENHORA DES GRACAS, NO. 50

XEREM, DUQUE DE CAXIAS

RIO DE JANEIRO

BRASIL 25250

MS. ESTEFANIA MARIA

LANGSDORFF SANCHES

FISICA

INMETRO

RUA SANTA ALEXANDRINIA, 416

RIO COMPRIDO

RIO DE JANEIRO

BRASIL 25250

MR. ROBERT A. HEWETT

SENIOR ADVISOR, STANDARDS AND REGULATIONS

NATIONAL RESEARCH COUNCIL OF CANADA

BUILDING M-20, MONTREAL ROAD

OTTAWA, ONTARIO

CANADA KIA OR6

DR. JACK PERROW

DIRECTOR， STANDARDIZATION

BRANCH

STANDARDS COUNCIL OF CANADA

$45 O^{\prime}$ CONNOR STREET, SUITE 1200

OTTAWA, ONTARIO

CANADA KIP $6 \mathrm{~N} 7$
DR. EDWARD MING-YANG WU

NATIONAL INSTITUTE OF

ENVIRONMENTAL ANALYSIS

ENVIRONMENT PROTECTION ADMINISTRATION

10F, NO. 233-2, PAO-CHIAO ROAD

HSIN TIEN CITY, TAIPEI, TAIWAN

REPUBLIC OF CHINA 231

MR. MILAN BERAN

DIPI. ING .

FEDERAL OFFICE FOR STANDARDS AND MEASUREMENT

VÁCLAVSKÉ NÁM. 19

11347 PRAHA 1

CZECHOSLOVAKIA

DR. LARS NIELSEN

DANISH INSTITUTE OF FUNDAMENTAL METROLOGY (DFM)

LUNDTOFTEVEJ 100, BLD. 307

LYNGBY

DENMARK DK-2800

MR . BO LINDHOLM

DIRECTOR

NORDTEST

P.O. BOX 111

ESBO

FINLAND SF-02101

M. ALAN BRYDEN

GENERAL DIRECTOR

LABORATOIRE NATIONAL D'ESSAIS LNE

1, RUE GASTON BOISSIER

PARIS

FRANCE 75015

$3 /$ Some countries had more than one person acting as head of the delegation. 
MR. WOLFGANG SCHIRMER

DIRECTOR

RAL DEUTSCHES INSTITUT FÜR GÜTESICHERUNG UND KENNZEICHNUNG EV

SIEGBURGER STRAßE 39

SANKT AUGUSTIN 3

GERMANY D-5205

DR. LAY HAR NG

HONG KONG LABORATORY

ACCREDITATION SCHEME - HOKLAS

INDUSTRY DEPARTMENT

$36 / F$., WANCHAI TOWER II

7 GLOUCESTER ROAD

WANCHAI

HONG KONG

MR. DEVI SARAN TEWARI

NATIONAL COORDINATION OF

TESTING AND CALIBRATION

FACILITIES - DEPARTMENT OF

SCIENCE AND TECHNOLOGY

NEW MEHRAULT ROAD

NEW DELHI

INDIA 110016

MR . KARIM HUSEIN

HEAD, ACCREDITATION DIVISION

PPMB CENTRE FOR TESTING AND

QUALITY CONTROL

JAN. RAYA BOGOR, KM. 26, CIRACAS,

KOTAK POS 4235

JAKARTA 13740

REPUBLIK INDONESIA

DR. FRANK T. SMYTH

HEAD OF SECRETARIAT

ILAB

GLASNEVIN

DUBLIN 9

IRELAND

MRS. ZIVA PATIR

DIRECTOR

QUALITY AND CERTIFICATION

DIVISION

STANDARDS INSTITUTE OF ISRAEL

42 CHAIM LEVANON STREET

TEL AVIV

ISRAEL 69977
MR . PAOLO BIANCO

CAMERA COMMERCIO TORINO

LABORATORIO CHIMICO

FOR UNION CAMERE - ROMA

VIA VENTIMIGLIA 165

TORINO

ITALY J-10127

MR. TAKESHI NAKADATE

OFFICE CHIEF

INTERNATIONAL TRADE AND INDUSTRY INSPECTION INSTITUTE

- MITI

49-10 NISHIHARA-2CHOME

TOKYO, SHIBUYA-KU

JAPAN 151

MR. KIM JONG HAN

DIRECTOR GENERAL

BUREAU OF INSPECTION, INDUSTRIAI ADVANCEMENT

ADMINISTRATION

2 JUNGANG-DONG

KWACHEN CITY, KYUNGGI-DO KOREA

MR. A. AZIZ MANAN

DIRECTOR OF TECHNICAL SERVICES - SIRIM

P.O. BOX 7035

KUALA LUMPUR SHAH ALAM

MALAYSIA 40911

DR. YOSHITO MITANI

CENTRO NACIONAL DE METROLOGIA

PERIFERICO SUR 3ER PISO

MEXICO, D.F.

MEXICO 10200

DR. JOS G. LEFERINK

STERLAB /NKO /STERIN

P.O. BOX 29152

3001 GD ROTTERDAM

THE NETHERLANDS 
DR. JACK H. GARSIDE

DIRECTOR

TELARC NEW ZEALAND

PRIVATE BAG 28901, REMUERA

AUCKIAND

NEW ZEALAND 1136

MR. JOSTEIN H. SOVIK

OPERATIONS DIRECTOR

SINTEF

STRINDVEIEN 2

TRONDHEIM

NORWAY N-7034

MR. XING-HAI ZHOU

DEPUTY DIRECTOR GENERAL

STATE ADMINISTRATION OF IMPORT

AND EXPORT COMMODITY

INSPECTION OF PRC

FANGCAODI XIJIE 15

BEIJING 100020

PEOPLES' REPUBLIC OF CHINA

MR. ANDRZEJ OZOG

DIRECTOR

CENTRAL OFFICE FOR PRODUCTS QUALITY

SWIETOKRZYSKA STR. 14B

O0-050 WARSAW

POLAAND PL 00-050

MR. YOUSSEF AL-ZAID

ASSESSOR - LABORATORY ACCREDITATION

STANDARDIZATION \& METROLOGY

ORGANIZATION FOR GULF

COOPERATION COUNCIL COUNTRIES

P.O. BOX 3437

RIYADH

SAUDI ARABIA 11471

MR. KONG HONG LAM

MANAGER, NATIONAL METROLOGY

CENTRE AND MANAGER,

LABORATORY ACCREDITATION

SINGAPORE INSTITUTE OF

STANDARDS AND INDUSTRIAL RESEARCH

1 SCIENCE PARK DRIVE

SINGAPORE 0511
MR. IAIN MACDONALD BENNIE

DIRECTOR

SOUTH AFRICAN BUREAU OF STANDARDS

PRIVATE BAG X191

PRETORIA, TRANSVAAL

SOUTH AFRICA 0001

MR . ANTONIO MUNOZ

CHAIRMAN

RED ESPANOLA DE LABORATORIOS DE

ENSAYO - RELE

AVDA. DE CONCHA ESPINA, 65, 2.0

MADRID

SPAIN 28016

MR. LARS ETTARP

DIRECTOR GENERAL

SWEDAC

BOX 878

S-501 15 BORAS

SWEDEN

MR. TRAKARN CHAIRAT

DEPUTY SECRETARY-GENERAL

THAI INDUSTRIAL STANDARDS

INSTITUTE (TISI)

MINISTRY OF INDUSTRY

RAMA VI STREET

BANGKOK 10400

THAILAND

MR. TARIK G. SOMER

PRESIDENT, PROFESSOR

TURKISH STANDARDS INSTITUTE

TSE, NECATIBEV CAD. NO. 112

ANKARA

TURKEY

MR . BILL HENDERSON

HEAD, NAMAS

NATIONAL PHYSICAL LABORATORY

QUEENS ROAD

TEDDINGTON, MIDDLESEX

UNITED KINGDOM TWII OLW 
MR. JOHN DONALDSON

MANAGER

STANDARDS CODE \& INFORMATION PROGRAM

NATIONAL INSTITUTE OF STANDARDS AND

TECHNOLOGY (NIST)

BUILDING 101, ROOM A629

GAITHERSBURG，MD 20899

U.S.A.

DR. NGUYEN HUU THIEN

DIRECTOR

REGIONAL CENTRE FOR

STANDARDIZATION, METROLOGY

AND QUALITY CONTROL

49 PASTEUR

HO CHI MINH CITY

VIETNAM 


\section{APPENDIX III - ISO/IEC GUIDE 25 QUESTIONNAIRE}

THIS SURVEY IS BEING CONDUCTED ON BEHALF OF ILAC. THE QUESTIONNAIRE IS TO BE COMPLETED AND RETURNED BY NOVEMBER 30, 1993 TO:

MAUREEN BREITENBERG

NIST

BUILDING 101, ROOM A629

GAITHERSBURG，MD 20899

USA

1. PROGRAM NAME:

2. ADDRESS :

PHONE :

FAX :

TELEX :

3. FIELDS OF TESTING COVERED BY THE PROGRAM: (Check as Appropriate) Biological Chemical Mechanical — Metrology Optics and photometry Ionizing Radiation Non-destructive Electrical other (Specify) Acoustic/Vibration Measurement

4. NUMBER OF LABORATORIES ACCREDITED: AS OF (Date):

5. IS LAABORATORY ACCREDITATION: VOluntarY Mandatory Other (Please Explain)

6. IS GUIDE 25 MENTIONED IN LAW OR REGULATION? YES NO 7. IS THERE A PUBLISHED LIST OF REQUIREMENTS FOR ACCREDITATION? YES NO IF YES, PLEASE SUPPLY.

8. ARE REQUIREMENTS CONSISTENT WITH GUIDE 25? YES NO WHICH EDITION? YEAR 
9. DO YOU HAVE GUIDANCE/INSTRUCTIONS THAT INTERPRETS/AMPLIFIES GUIDE 25 REQUIREMENTS? YES — NO __ (If no, skip to end.)

10. DOES GUIDANCE/INSTRUCTIONS VARY BY TEST FIELD? YES __ NO

11. FOR WHICH SECTIONS OF GUIDE 25 HAVE YOU PROVIDED SUCH ADDITIONAL GUIDANCE/INSTRUCTIONS? (Numbers Correspond to Sections of 1990 Edition)

4. Organization \& Mgt. .....

5. System Audit/Review Quality Manual/Doc. Internal Audits ........ Corrective Actions/Doc.

6. Personnel Training/Experience ..... Conflict of Interest Req.

7. Accommodation/Environment Laboratory Facilities ... Environmental Conditions

8. Equipment/Ref. Materials Types of Equipment ...... Equipment Labeling/Doc.

9. Traceability \& Calibration Equipment Calibration ... Measurement Traceability Standards Ref. Materials

10. Calibration/Test Methods Calibration Instructions Test Method Requirements Test Method Documentation Test Method Availability

11. Handling Calibration/Test Items

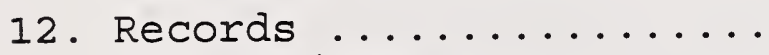
Content/Format ......... Retention Period
13. Certificates Content/Format Modifications Client Notification

14. Subcontracting Work Eligible for Subcontracting ........ Subcontractor Competency Requirements

Client Notification

15. Outside Support Services and Supplies .......... Evaluation of Quality ... Supplier Records .......

16. Complaints ............ Doc. of Complaints ..... Appeals Process

\section{OTHER}

a. Sampling

b. Laboratory Safety

c. Site Testing

(Specify Additional Requirements) d.

e.

f.

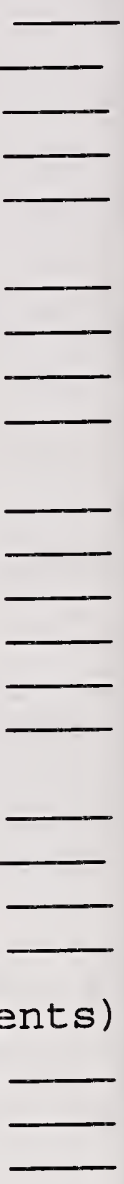

PLEASE ATTACH LIST OF ANY SUCH DOCUMENTS, NOTING MATCH TO ITEMS LISTED ABOVE.

ARE THESE DOCUMENTS AVAILABLE IN ENGLISH? (if program operates in language other than English) YES _ NO

QUESTIONNAIRE PREPARED BY:

TITLE :

DATE : 


\section{APPENDIX IV}

\section{LIST OF U.S. ACCREDITATION REQUIREMENTS DOCUMENTS BY PROGRAM}

(For the Full Names and Addresses of the Programs, See Appendix VI)

American Association for Laboratory Accreditation (A2LA):

Has additional guidance. Documents include: "General Requirements for Accreditation;" "Environmental Program Requirements;" "Fertilizer Program Requirements;" "Geotechnical Program Requirements;" "Construction Materials Testing Program Requirements;" "Nondestructive Program Requirements;"

Federal Communications Commission (FCC) Test Site Listing Program: Requirements are contained in 47 CFR 2.948. Requirements are not consistent with Guide 25.

Lockheed Missiles and Space Co.

Has additional guidance, but documents were not identified.

Nationally Recognized Laboratory (NRTL) Program - Laboratory Assessment Mine Safety and Health Administration/DOL:

Requirements are consistent with (but not based on ISO/IEC Guide 25). Requirements are contained in 29 CFR 1910.7, Appendix A.

National Voluntary Laboratory Accreditation Program (NVLAP/NIST): NVIAP specifically references Guides $25,38,43,58$, and applicable ISO 9000 standards in the 15 CFR Part 285 which contains NVLAP's general requirements. Specific requirements for individual LAP's are contained in NVIAA Handbooks. In the information technology and telecommunications (IT\&T) area, NVIAP uses the interpretative guide developed by ECICT/WELAC, NIST, ANSI and others. For calibration, NVLAP will be using ANSI/NCSL Z540 "General Requirements for Calibration Laboratories and Measuring and Test Equipment."

Office of Weights and Measures/NIST - State Laboratory Program:

NVLAP and the state Laboratory Accreditation Program will incorporate ANSI/NCSL Z540 "General Requirements for Calibration Laboratories and Measuring and Test Equipment" into their program requirements. This standard references ISO/IEC Guide 25 along with appropriate military standards for the evaluation of calibration laboratories and the testing of measuring and test equipment. 


$$
20
$$




\section{APPENDIX V}

LIST OF ACCREDITATION REOUIREMENTS DOCUMENTS BY COUNTRY/PROGRAM

(For the Full Names and Addresses of the Programs, See Appendix VI)

AUSTRALIA - National Association of Testing Authorities (NATA):

Requirements are included in "General Requirements for Registration."

BELGIUM - BELTEST:

Did not complete the questionnaire because the program still in development stage. Program will be based on a law passed July 20, 1990 and on the EN 45000 series.

BELGIUM - BELGIUM CALIBRATION ORGANIZATION:

Did not complete the questionnaire. Program will be based on the Royal Decree of November 28, 1976 and WECC documents. The list of documents is in French.

BRAZIL - Instituto Nacional de Metrologia, Normalizacao e Qualidade Industrial (INMETRO):

Does not have guidance that interprets/amplifies ISO/IEC Guide 25.

CANADA - Canadian General Standards Board (CGSB) Laboratory Acceptance: Requirements are contained in the document "Listing Program for the Acceptance of Testing Laboratories," but does not have guidance that interprets/amplifies ISO/IEC Guide 25.

CANADA - Standards Council of Canada (SCC) Program for Accreditation of Laboratories

Has documents which interpret/amplify ISO/IEC Guide 25 requirements. Requirements are contained in CAN-P-4C, General Requirements for the Accreditation of Calibration and Testing Laboratories; CAN-P-1515, Conditions for the Accreditation of Calibration and Testing Laboratories; and CAN-P-1510C, Guidelines for Preparing an Application for Accreditation for Calibration and Testing Laboratories.

CANADA - Canadian Association for Environmental Analytical Laboratories (CAEAL), InC.:

Did not answer questions on availability of guidance that interprets/ amplifies on ISO/IEC Guide 25. Requirements are contained in the CAEAL Rating Guide and Appendix to Rating Guide.

CANADA - Quebec Ministry of Environment (MENVIO):

Does not have guidance that interprets/amplifies ISO/IEC Guide 25.

CANADA - Accreditation des Laboratoires et des organismes d'Inspection/BNO: Has guidance (not identified) that interprets/amplifies ISO/IEC Guide 25 Documents are currently being translated.

CHINA - Chinese National Laboratory Accreditation (CNLA):

Has guidance that interprets/amplifies ISO/IEC Guide 25. Accreditation requirements are contained in the List of Accreditation Requirements. 
CZECHOSLOVAKIA - Czech Accreditation system:

Has guidance that interprets/amplifies ISO/IEC Guide 25. Requirements are contained in MPA 001 - 93 Directions on the Application of CSN EN 45001 in the Accreditation system of the Czech Republic; MPA 090 - 93 Instructions for Elaboration of the Quality Manual of a Laboratory; and the Law on Metrology No. $505 / 1990$ (C. of L).

FRANCE - Reseau National d'Essais (RNE):

Has guidance that interprets/amplifies ISO/IEC Guide 25. Most of the instructions are listed in the document, DOC RNE 15 (not available in English, though some of the documents listed have been translated.) DoC RNE 19 Requirements to be Satisfied by Accredited Testing Laboratories or Candidates for Accreditation, and Modes of Application, is available in English and contains EN 45001 with RNE application instructions.

GERMANY - Testing and Certification of Electrical Equipment and Components:

Has no guidance which interprets/amplifies IsO/IEC Guide 25.

HONG KONG - Hong Kong Laboratory Accreditation Scheme (HOKLAS):

Requirements for accreditation are contained in the following documents: 1. External Guideline 1/87: Construction Materials Test Category - Force Calibration Interim Arrangements (Item 9)

2. External Guideline 1/88: All Test Categories - Equipment Calibration Requirements (Item 9)

3. External Guideline 2/88: (Issue No. 3) (Revised) Requirements for Accreditation - Calibration of Traders Weight and Balances (Item 9) 4. External Guideline 4/88: (Issue No. 2) Guide on Advertising Criteria (Item Not Identified)

5. External Guideline 5/88: Environmental Test Category - Asbestos Sampling and Testing (Items 6-13,a)

6. External Guideline 1/89: HOKLAS Guideline - Quality Audits (Item 5)

7. External Guideline 2/89: Environmental Test Category - Microbiological

Testing (Items 6-13)

8. External Guideline 3/89: Toys Commodity Group - Mechanical and Physical Testing (Items 6-13)

9. External Guideline 4/89: Environmental Test Category - Toys Test Category - Determination of Play Value of a Toy (Item 10)

10. External Guideline 1/92: "Chemical Testing" Test Category -

Accreditation of Racing Control Laboratories Involved with Detection, Identification and Determination of Prohibited Substances (I) in Biological Samples (Item 10)

11. External Guideline 2/92: Environmental Test Category - Accreditation of Site Testing/Sampling (Water, Wastewater and Sediment) (Items $a, c$ )

12. HOKLAS 002 (3rd edition) - HOKLAS "Regulations for Laboratory

Accreditation" (Items e,f) provided in English.

13. HOKLAS 003 (3rd edition) - HOKLAS "Technical Criteria for Laboratory Accreditation" (Items 4-16, a, c, d) provided in English.

14. HOKLAS 004 (2rd edition) - HOKLAS "Guidelines for Preparation of Laboratory Quality Manual" (Items not identified) 
15. HOKLAS 005 (2rd edition) - HOKLAS "Application for Laboratory

Accreditation" (Items not identified)

16. HOKLAS 007 - HOKLAS "Application Questionnaire" (Items not identified)

17. HOKLAS 008 - HOKLAS "Guide for Hong Kong Assessors" (Items not

identified)

18. HOKLAS 009 HOKLAS "Directory of Accredited Laboratories in Hong Kong" 1992-3 (Items not identified)

19. HOKLAS 010 HOKLAS "Application for the Extension of Scope of Laboratory

Accreditation" (Items not identified)

20. HOKLAS 011 HOKLAS "Application for Change/Additional Authorized

Representative" (Items not identified)

INDIA - National Accreditation Board for Testing \& Calibration

Laboratories:

Some of the amplification/interpretation is contained the chapter of "Supplementary information in NABL Criteria for Laboratory Accreditation (1992) document."

INDONESIA - Accreditation of Testing Laboratory for Export Products:

Has guidance that interprets/amplifies ISO/IEC Guide 25 (some in English), but documents were not identified.

ISRAEL - Standards Institution of Israel (SII):

ISO/IEC Guide 25 is not mentioned and there is no published list of requirements for accreditation.

ISRAEL - National Calibration Accreditation:

Law/requirements references the EN 45000 Series. There are no additional requirements.

ITALY - Sistema Nazionale per l'Accreditamento de Laboratori (SINAL):

Accreditation requirements are contained in the following documents:

1. DI-0001 - Introducing SINAL

2. DG-0001 - SINAL General Regulations

3. DG-0002 - Regulations for using SINAL logo

4. DG-0003 - Accreditation agreement between SINAL and the testing

Laboratory

5. DG-0004 - Accreditation agreement between SINAL and the body

responsible for the Laboratory

6. DG-0007 - General requirements for the Accreditation of testing

Laboratories

7. PG-0001 - General procedures for Accreditation of a testing Laboratory

8. PG-0001/2 - Application form for Accreditation

9. PG-0002 - General procedure for assessment of testing Laboratories

10. PG-0003 - Proficiency tests

11. PT-0001 - Guide to the compilation of a quality manual for a testing

Laboratory

12. PT-0002 - Guide for defining the tests to be accredited

13. PT-0003 - Traceability of measurement 
14. PT-0005 - Criteria for registration of SINAL assessors

15. Directory of SINAL accredited testing Laboratories and of Calibration

Centres in Italy

KOREA - Laboratory Accreditation Scheme and the Weights \& Measures Act: Documents (not identified) expected to be translated by end of year.

MALAYSIA - Laboratory Accreditation Scheme of Malaysia (SAAM):

Has additional guidance, but documents were not identified.

MEXICO - Systema Nacional de Calibration:

Has no additional guidance/instructions. Documents (available only in Spanish) include: Recommendation SNC-D-2-1989: Directrices Para Evaluar La Competencia **Tecnica de un Laboratorio de Metrologia; SNC-D-11-1989: Directrices y Procedimiento Para la Evaluacion de un Laboratorio de Metrologia e Interpretacion de Requisitos Minimos; and Directrices Para la Evaluacion de un Laboratorio de Metrologia e Interpretacion de Requisitos Minimos.

NETHERLANDS - NKO/STERIN/STERLAB:

Has guidance that interprets/amplifies ISO/IEC Guide 25, which is covered in SC OO-Common Criteria (available in English), SC 01-Supplementary Criteria for Test Laboratories (available in English), SC 05-Supplementary Criteria for Calibration Laboratories (available in English), and SC 06Tables of Reference (available in English). Additional information is contained in SRS 002-Rules for the Assessment, Accreditation and Surveillance of Laboratories and Inspection Bodies and SMT 035-General Information (available in English).

NEW ZEALAND - TELARC:

Has guidance the interprets/amplifies ISO/IEC Guide 25. Documents include: New Zealand Code of Laboratory Management Practice and Registered

Laboratory Programme. Other documents include Technical Guides on: Simple linear measurement instruments, their use, care and calibration; Laboratory balance - calibration requirements; Working thermometers - calibration procedures; UV/Vis spectrophotometers - calibration procedures; Precision and limits of detection for analytical methods, a guide to the operation of flame atomic absorption; and Quality manuals for testing laboratories.

Technical Notes include: Testing of soils; Nondestructive testing; Criteria for the registration of organizations undertaking the assessment of mechanical tests and the interpretation of radiographs in accordance with NZS 4711; Criteria for registration for concrete testing by on-site personnel; Gas cylinder testing; Testing of paints; Early fire hazard tests to AS 1530: Part 3; Magnetic particle and penetrant inspections; Gas meter testing; and Criteria for registration for sampling construction materials by on-site personnel. Specific Criteria Schedules include: Applied Physics; Biological Testing; Chemical Testing; Dairy Testing Laboratories Number 1; Electrical Laboratories - Number 5; Mechanical Testing; Medical Testing; Metrology Laboratories - Number 2; and Sampling Wool for Testing and Certification - Number 4. 
NORWAY - Norwegian Accreditation:

Guidance which amplifies/interprets ISO/IEC Guide 25 is primarily contained in NA Dok 10 (available in English). Accreditation is based on EN 45001/2/3. Also uses WECC doc. 11-91, WECC doc. 13-91, WECC doc. 14-91, WECC (89) 1, WECC doC. 19-90, WECC doC. 12-90, WELAC WGD 1, WELAC WGD 2, and WELAC WGD 4 .

POLAND - National accreditation scheme of testing laboratories in Poland: Has one document (not available in English and not identified) which covers all accreditation requirements.

SINGAPORE - Singapore Laboratory Accreditation Scheme (SINGLAS):

Guidance/instructions have been developed for SINGLAS's own internal use (for assessors); however, laboratories are normally given some advice on ISO/IEC Guide 25. SINGLAS documents include: SINGLAS 001 - The Singapore Laboratory Accreditation Scheme Regulations; SINGLAS 002 - General

Requirements for the Competence of Calibration and Testing Laboratories; SINGLAS 004 -Classification of Tests; and Technical Notes for the fields of Chemical and Biological Testing, Mechanical Testing, Calibration and

Measurement, Civil Engineering Testing, Non-Destructive Testing, Electrical

Testing.

SWEDEN - Swedish Board for Technical Accreditation (SWEDAC):

Does not have guidance that amplifies/interprets ISO/IEC Guide 25. Basic requirement document for accreditation is EN 45001 for the accreditation of labs. Interpretative documents are focused around that standard and EN 45002. The list of interpretative documents are WELAC/WECC documents.

SAUDI ARABIA - Accreditation of Laboratories:

Requirements for accreditation are included in the following documents: 1. Quality Mark, Certificate of Conformity, \& Accreditation of Services Regulations

2. Quality Mark, Certificate of Conformity, \& Accreditation of Services Regulations - Accreditation of Laboratories - Explanatory Note L.A. (6) Quality Audits and Reviews

3. Quality Mark, Certificate of Conformity, \& Accreditation of Services Regulations - Accreditation of Laboratories - Explanatory Note No. L.A. - Calibration and Traceability of Measurement

4. Quality Mark, Certificate of Conformity, \& Accreditation of Services Regulations - Accreditation of Laboratories - Explanatory Note No. L.A. -Guidance Notes for Preparation of Laboratory Quality Control Manual

THAILAND - Thai Industrial Standards Institute:

Does not have guidance that interprets/amplifies ISO/IEC Guide 25.

UNITED KINGDOM - National Measurement Accreditation Scheme (NAMAS):

NAMAS has an accreditation standard which contains ISO/IEC Guide 25 plus some extra clauses to ensure requirements are understood and applied consistently by laboratories and assessors. It has large guidance documents on traceability, calibration measurement systems, audit and review and quality manuals. Such text could not be included in ISO/IEC Guide 25. NAMAS also has a large number of technical requirements/guidance 
documents to explain how to apply ISO/IEC Guide 25 in specific fields. NAMAS has specific additional interpretations of ISO/IEC Guide 25 for sampling and site testing which NAMAS believes essential for consistent interpretation by assessors.

List of NAMAS publications containing general accreditation criteria include:

- M10 NAMAS Accreditation standard

- M10 Measurement and Calibration Systems

- M11 NAMAS Regulations

Publications contain generally applicable requirements include:

- M13 Conditions for Use of NAMAS Logo or Reference to NAMAS Accreditation by NAMAS Accredited Laboratories

- M17 Accreditation for Sampling for Accredited Laboratories

- Accreditation for Site Calibration and Testing

- Certificates of Calibration

Publications related to assessment include:

- M20 NAMAS Assessor Acceptability standard

- M21 The Conduct of NAMAS Assessments; Procedures for Assessors [Available only to NAMAS assessors]

- M22 The Conduct of NAMAS Assessments: A Guide for Laboratories

Publication related to traceability is:

- M50 Traceability of Measurement: General Policy

Publications related to schedules include:

- M52 Schedules of Accreditation and Applications for Extension of Accreditation

Publications related to quality systems include:

- M16 The Quality Manual: Guidance for Preparation

- M51 Quality Audit and Quality System review in Calibration and Testing Laboratories

NAMAS also has NIS documents covering more specialized guidance documents for testing and calibration laboratories. 


\section{NON-U.S.Respondents}

\section{AUSTRALIA}

National Association of Testing Authorities (NATA)

7 Leeds Street

Rhodes

New South Wales

Australia 2138

Phone: (02) 7368222

Fax: (02) 7435311

2. BRAZIL

Instituto Nacional de Metrologia, Normalizacao e Qualidade Industrial (INMETRO)

Rua Santa Alexandrina, 416/ $7^{\circ}$ andar

20261-232 Rio De Janeiro - RJ

Brazil

Phone: +55 212934241

Fax: $\quad+55212931564$

\section{CANADA}

Canadian General Standards Board (CGSB) Laboratory Acceptance Program CGSB

222 Queen Street, Suite 1402

Ottawa, Ontario K1A $1 \mathrm{G} 6$

Canada

Phone: (613) 941-8654

Fax: (613) 941-8706

4. CANADA

Standards Council of Canada (SCC) Program for Accreditation of Laboratories

1200 - 45 o'Connor street

Ottawa, Ontario

Canada

Phone: (613) 2383222

Fax: (613) 9954564

Telex: 0534403 (STANCAN OTT)

5. CANADA

Quebec Ministry of Environment (MENVIQ)

360 rue Franquet, bureau 40

Sainte-Foy (Quebec) GIP 4N3

Canada

Phone: (418) 646-6898

Fax: (418) 528-1091 
6. CANADA

Canadian Association for Environmental Analytical Laboratories (CAEAL) Inc.

Suite 532 - 1 Nicholas street

Ottawa, Ontario KIN 7B7

Canada

Phone: 613-562-2200

Fax: $\quad 613-562-2203$

7. CANADA

Accreditation des Laboratoires et des Organismes d'Inspection/BNQ

70 rue Dalhousie

bureau 220

Quebec (Quebec) G1K 4B2

Canada

Phone: (418) 643-5813

Fax: (418) 646-3315

8. CANADA

Service Soutien a l'assurance qualite

Ministere des Transports

200, rue Dorchester Sud, 3eme etage

Quebec (Quebec) GIK 5Z1

Canada

Phone: 418-643 1486

Fax: $\quad 418-646-5415$

9. CHINA-TAIWAN

Chinese National Laboratory Accreditation (CNLA)

Bldg. 16, 321 Section 2 Kuang-Furd

Hsin-Chu

Taiwan.

Phone: 886-35-721 321

Fax: $886-35-716231$

10. CZECHOSLOVARIA:

Czech Accreditation system

Czech Accreditation Institute (CAI)

Vaclavske nam.c.19

11347 Praha 1

Czech Republic

Phone: +42224229405

Fax: $\quad+42224229405$

11. FINLAND

Finnish Accreditation Service (FINAS)

P. O. Box 237

00181 Helsinki

Finland

Phone: +358061671

Fax: $\quad+35806167467$ 
12. FRANCE

Reseau National d'Essais (RNE)

77 rue du Pere Corentin

75014 Paris

France

Phone: +33140520570

Fax: $\quad+33140520571$

\section{GERMANY}

Testing and Certification of Electrical Equipment and Components

VDE Pruf- und Zertifizierungsinstitut

MerianstraBe 28

D-63069 Offenbach/Main

Germany

Phone: $+49698306-0$

Fax: $\quad+49698306-555$

Telex: 4152796 vdep d

14. HONG RONG

Hong Kong Laboratory Accreditation Scheme (HOKLAS)

Industry Department

36th Floor, Immigration Tower

7 Gloucester Road

Wanchai

Hong Kong

Phone: 8294802

Fax: 8241302

Telex: 50151 INDHK HX

15. INDIA

National Accreditation Board for Testing and Calibration Laboratories

Department of Science and Technology

Technology Bhawan

New Mehrauli Road

New Delhi 110016

India

Phone: 6864642

Fax: $661682,6863847,6862418$

Telex: 73317, 73280, 73381

16. INDONESIA

Accreditation of Testing Laboratory for Export Products

JIn. Raya Bogor $\mathrm{Km} .26$ Jakarta Timur

Indonesia

Phone: (021) 8710321-23

Fax: (021) 8710478 
17. ISRAEL

Standards Institution of Israel (SII)

Accreditation Committee

42 Chaim Levanon Street

Tel-Aviv

Israel

Phone: 972-3-646-5144

Fax: $\quad 972-3-646-5205$

18. ISRAEL

National Calibration Accreditation

National Physical Laboratory of Israel

Danciger A Bldg.

Givat-Ram

Jerusalem 91904

Israel

Phone: 972-266-1856

Fax: $\quad 972-252-0797$

19. ITALY

Sistema Nazionale per l'Accreditamento de Laboratori (SINAL)

via Campania 31

00187 Roma

Italy

Phone: +39 64871141

Fax: $\quad+39 \quad 6 \quad 4814563$

20. ROREA

Laboratory Accreditation Scheme and the Weights and

Measures Act

2 Chungang-dong

Kwacheon-city

Kyonggi-do 427-010

Republic of Korea

Phone: 8225037734

Fax: 8225045282

21. MALAYSIA

Laboratory Accreditation Scheme of Malaysia (SAAM)

Standards and Industrial Research Institute of Malaysia (SIRIM)

Persiaran Dato' Menteri, Section 2

P.O. Box 7035

40911 Shah Alam

Selangor Darul Ehsan

Malaysia

Phone: 03-5509484

Fax: (603) 5509439

Telex: SIRIM MA 38672 


\section{MEXICO}

Systema Nacional de Calibration

Secretaria de Comercio y Fomento Industrial

Direccion General de Normas (DGN)

Puente de Tecamachalco No. 6

Lomas de Tecamachalco

Seccion Fuentes

53950 Naucalpan de Juarez

Mexico

Phone: (52 5) 5400451

Fax: $\quad\left(\begin{array}{ll}52 & 5\end{array}\right) \quad 5400153$

23. NETHERLANDS

NKO/STERIN/STERLAB

P.O. BOX 29152

3001 G D Rotterdam

Netherlands

Phone: +31 104136011

Fax: +31 104133557

24. NEW ZEALAND

TELARC

Private Bag 28-901

Remuera, Auckland

New Zealand

Phone: 006495250100

Fax: 006495251900

25. NORWAY

Norwegian Accreditation

P.O. Box 6832

St. Olavs Plass

N-0130 Oslo

Norway

Phone: 4722200226

Fax: 4722207772

26. POLAND

National accreditation scheme of testing laboratories in Poland Central Office for Products Quality - CBJW

Swietokrzyska, 14B str.

Warsaw PL00-050

Poland

Phone: $+4822 \quad 277071$

Fax: $\quad+4822 \quad 26 \quad 6765$

Telex: 816196PL 
27. SAUDI ARABIA

Accreditation of Laboratories

P. O. Box 3427

Riyadh 11471

Saudi Arabia

Phone: 479-3332

Fax: $479-3063$

Telex: 401610 SASO SJ

28. SINGAPORE

Singapore Laboratory Accreditation Scheme (SINGLAS)

No. 1 Science park Drive

Singapore 0511

Phone: (65) 778-7777

Fax: (65) 776-1280

29. SWEDEN

Swedish Board for Technical Accreditation (SWEDAC)

Box 878

50115 Boras

Sweden

Phone: +4633177700

Fax: $\quad+4633101392$

30. THAILAND

Thai Industrial Standards Institute

Rama VI Street

Rajathevee

Bangkok 10400

Thailand

Phone: (662) 2457802

Fax: $\quad(662) 2481550$

31. UNITED RINGDOM

National Measurement Accreditation Scheme (NAMAS)

NAMAS Executive

National Physical Laboratory

Teddington, Middlesex

U.K.

Phone: 081-943-6168

Fax: $\quad 081-943-7134$

\section{U.S. Respondents}

1. Office of Weights and Measures

State Laboratory Program

NIST

Building 101, Room A617

Gaithersburg, MD 20899

Phone: (301) 975-4004

Fax: (301) 926-0647 
2. Federal Communications Commission

Test Site Listing Program

7435 Oakland Mills Road

Columbia, MD 21046

Phone: $301-725-1585$

Fax: $\quad 301-344-2050$

3. Nationally Recognized Laboratory (NRTL) Program - Laboratory Assessment Mine Safety and Health Administration/DOL

Tridelphia, WV 26059

Phone: 304-547-0400

Fax: $\quad 304-547-0400$

4. National Voluntary Laboratory Accreditation Program (NVLAP)

NIST

TRF Building, Room A162

Gaithersburg, MD 20899

Phone: (301) 975-4042

Fax: (301) 926-2884

5. American Association for Laboratory Accreditation (A2LA)

656 Quince Orchard Road

Gaithersburg, MD 20878-1409

Phone: (301) 670-1377

Fax: (301) 869-1495

6. Lockheed Missiles and Space Company

(Programs such as TRIDENT II, MILSTAR, THAAD, SPACE STATION, etc.

P. O. Box 3504, B195A, 0/48-70

Sunnyvale, CA 94089

Phone: 408-756-0270

Fax: $\quad 408-742-4435$ 
The following is a breakdown of the U.S. and non-U.S. responses regarding the need for additional supplementation of ISO/IEC Guide 25:

\section{TOTAL U.S. RESPONSES \\ SECTIONS OF GUIDE 25 WITH THE MOST ADDITIONAL GUIDANCE/INSTRUCTIONS \\ (Sub-items are listed in parentheses)}

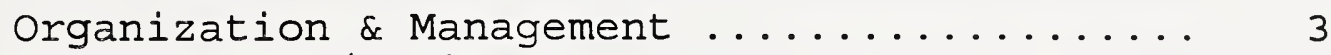

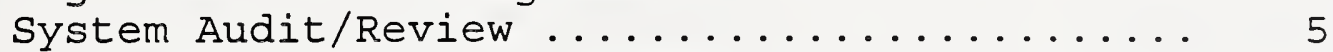

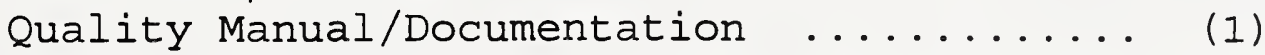

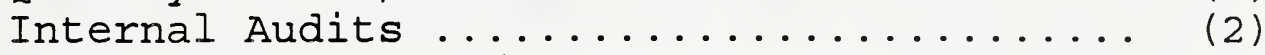

Corrective Actions/Documentation ......... (1)

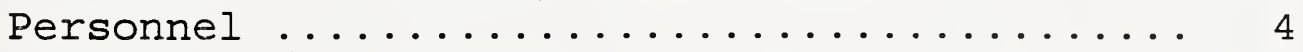

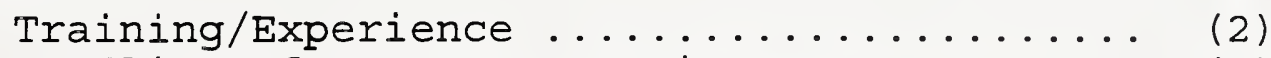

Conflict-of-Interest Requirements ........ (0)

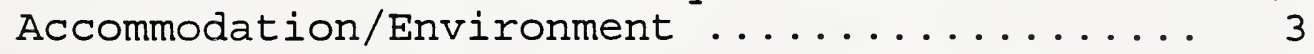

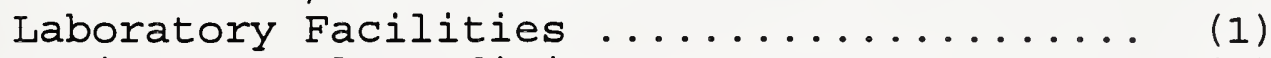

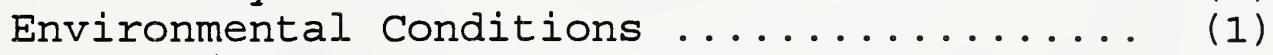

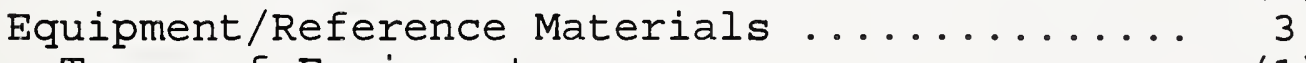

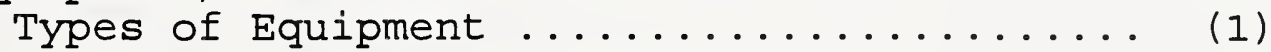

Equipment Labeling/Documentation .......... (1)

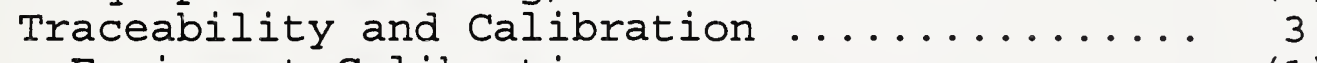

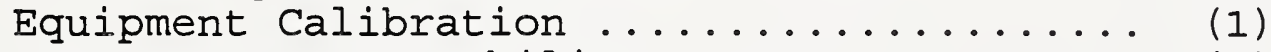

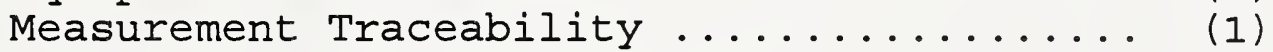

Standards Reference Materials ............ (1)

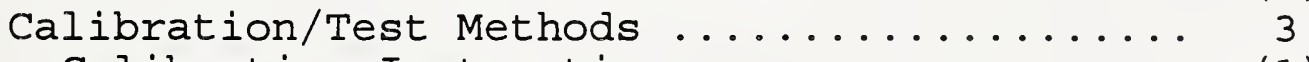

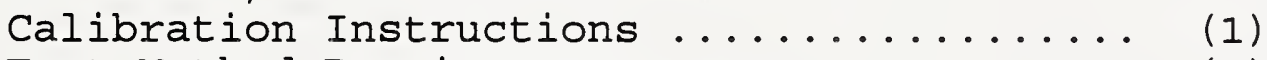

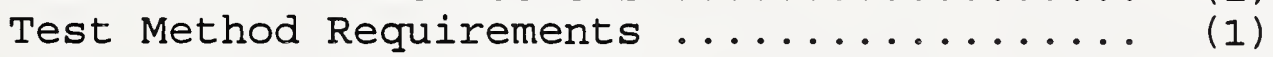

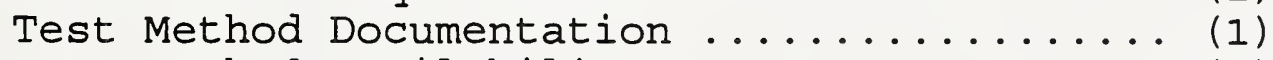

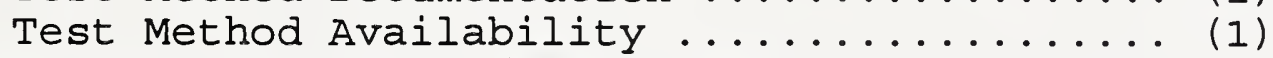

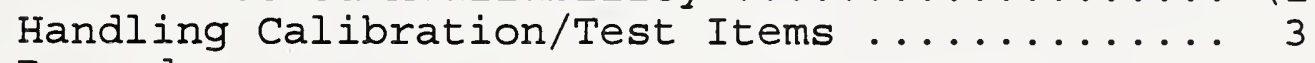

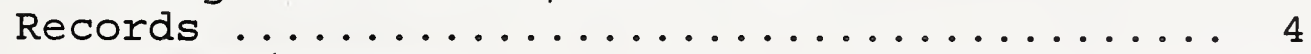

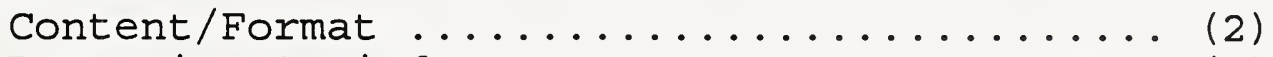

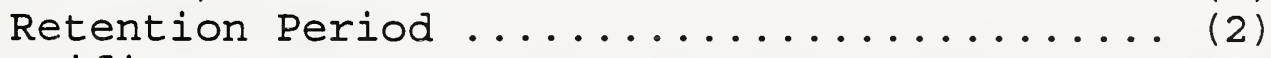

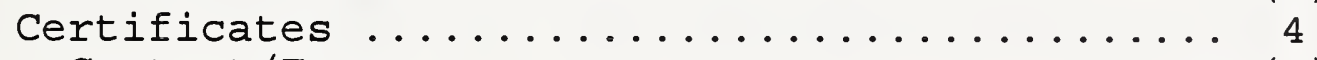

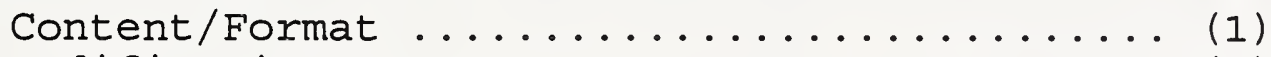

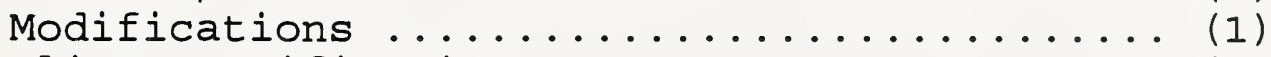

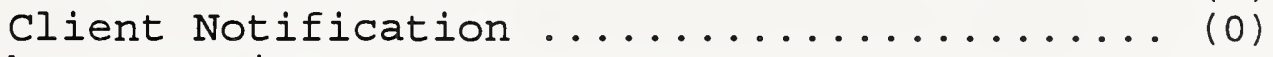

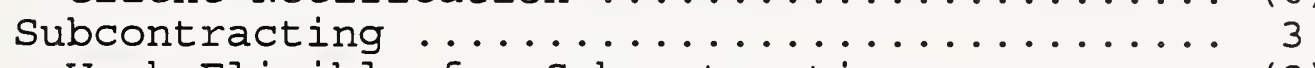

Work Eligible for subcontracting ........... (2)

Subcontractor Competency Requirements ...... (2)

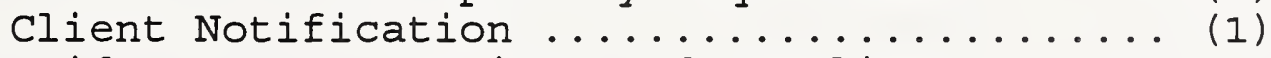

Outside support services and supplies ........ 3

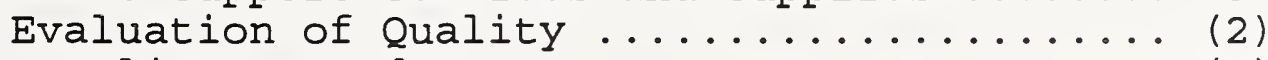

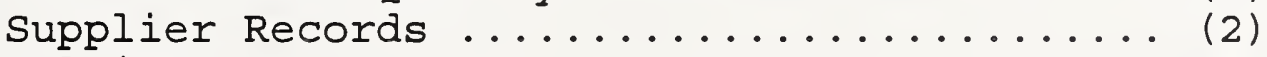

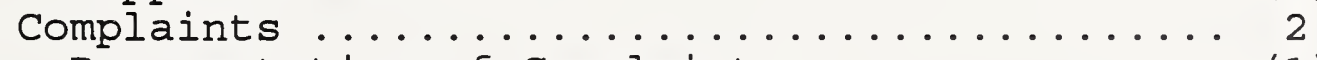

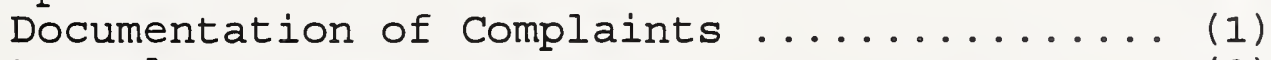

Appeals Process ...................... (0)

OTHER

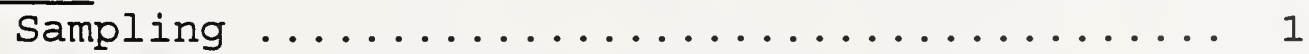

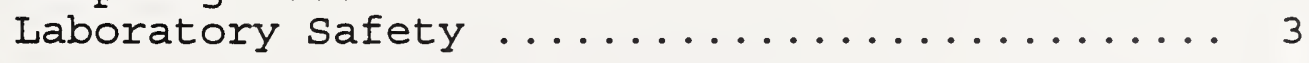


(Sub-items are listed in parentheses)

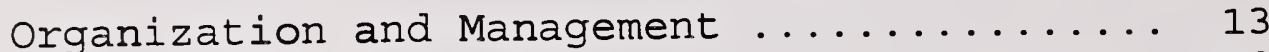

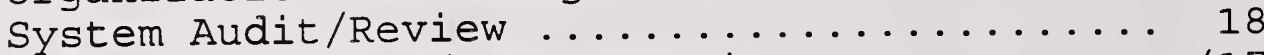

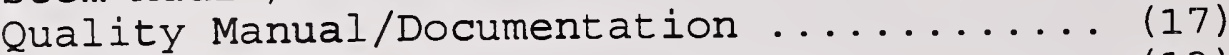

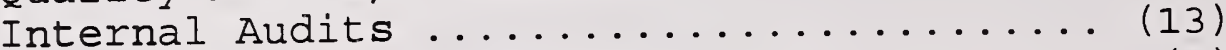

Corrective Actions/Documentation ......... (7)

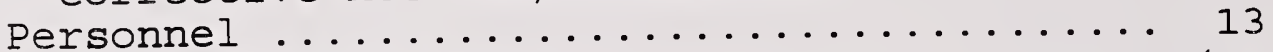

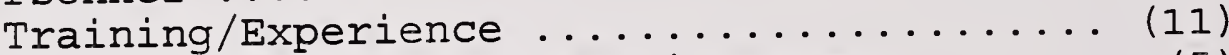

Conflict-of-Interest Requirements ....... (5)

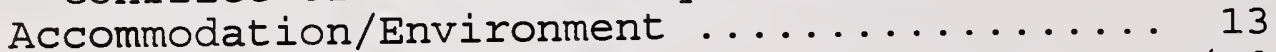

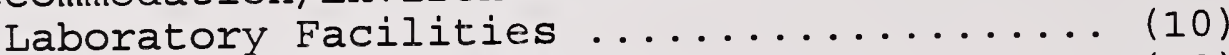

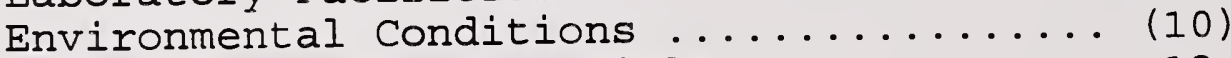

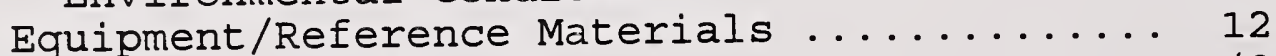

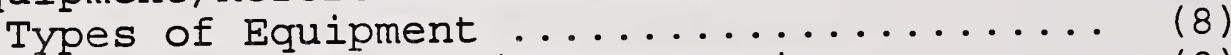

Equipment Labeling/Documentation ......... (8)

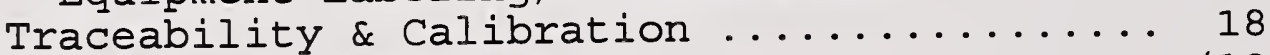

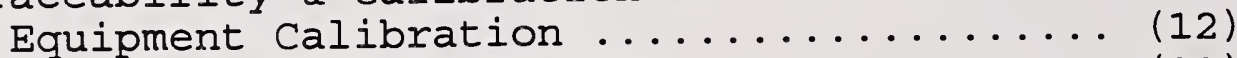

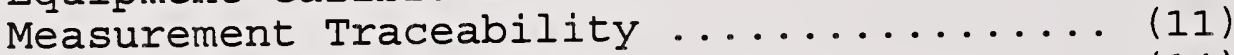

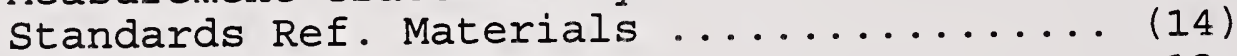

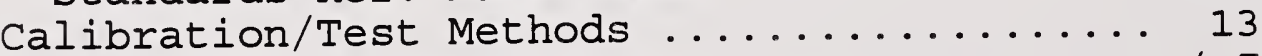

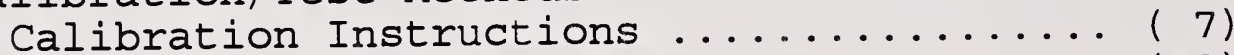

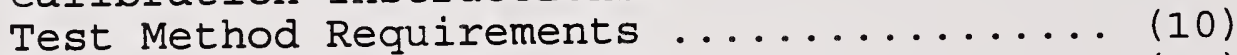

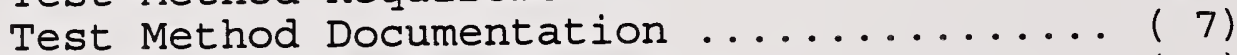

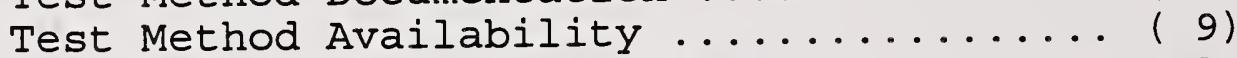

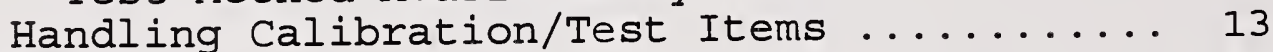

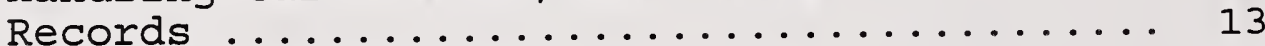

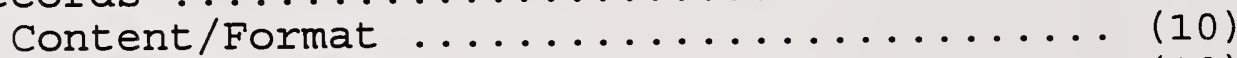

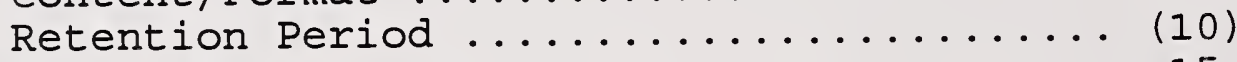

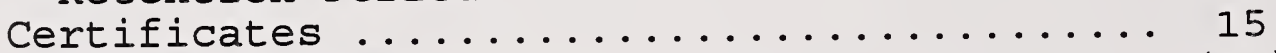

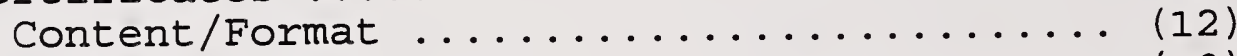

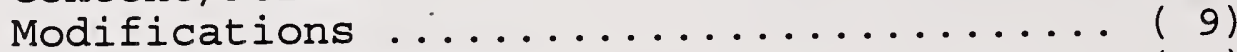

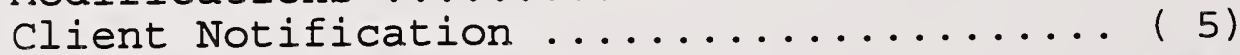

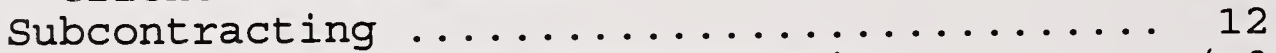

Work Eligible for Subcontracting ......... (9)

Subcontractor Competency Requirements .... (9)

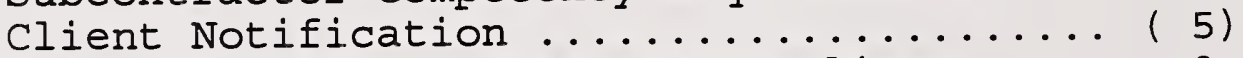

Outside Support Services and Supplies ..... 8

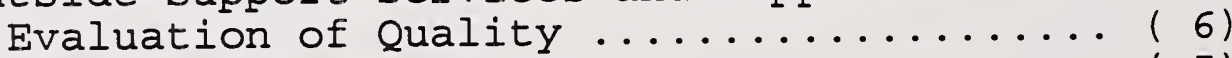

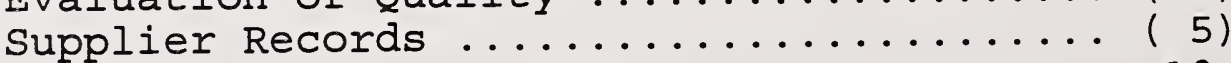

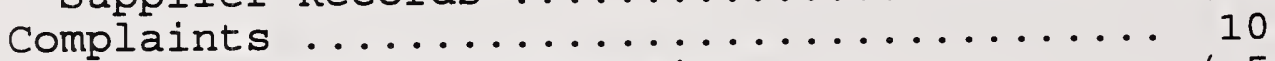

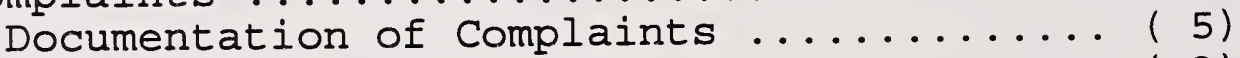

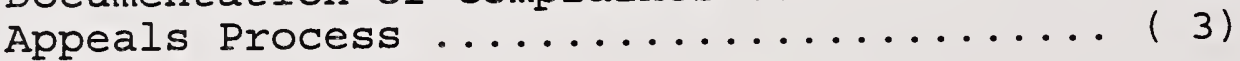

OTHER

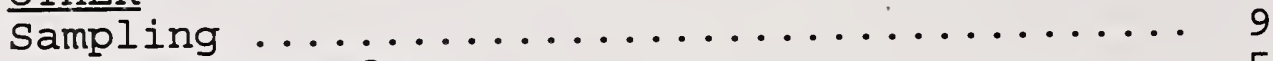

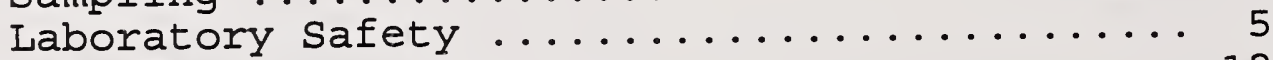

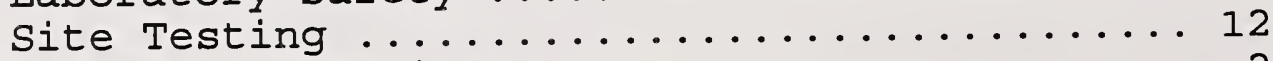

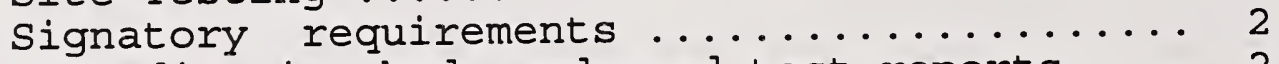

Accreditation body endorsed test reports .... 2

Subcontracting by accredited lab only ...... 1

Inspection for certification program ....... 1

Additional requirements for calibration labs 1

Verification practices .................... 1

Confidentiality and proprietary rights ..... 1 


\section{ISO/IEC GUIDE 25 QUESTIONNAIRE - U.S. SURVEY SUMMARY}

Eight responses were received on six programs. Two responses were received from the Occupational Safety and Health Administration (OSHA) and the Mine Safety and Health Administration (MSHA) on the Nationally Recognized Testing Laboratory (NRTL) Program which contained different responses. Information from MSHA was used, because their information related only to the laboratory accreditation portion of the program. Two responses were also received from National Voluntary Laboratory Accreditation Program (NVLAP). The response from the head of NVLAP was used.

NO. OF LABORATORY PROGRAM RESPONSES 6

FIELDS OF TESTING COVERED BY THE PROGRAM:

Biological

Chemical

Ionizing Radiation

Electrical

Mechanical

Metrology

5
4

Non-destructive

Thermal

Optics and Photometry 1

Acoustic/Vibration Measurement 3

Other (Specify) environmental-1; most programs are product oriented-1;

NUMBER OF LABORATORIES ACCREDITED: 1; 8 (2 grandfathered in); approx. 55; 477; 567; approx. 1000

LABORATORY ACCREDITATION: Voluntary 1 Mandatory - Other 5 Some programs are required by law, others are not; mandatory for certain products, but voluntary for labs - 2 responses: Program is voluntary, though some states have legal requirement to maintain accreditation: mandatory only for labs involved in areas covered by Memorandum of Understanding with the U.S. Environmental Protection Agency.

GUIDE 25 MENTIONED IN LAW OR REGULATION: YES 1 NO 3 Other 2 * Mentioned in MOU with EPA; *Some state reference ISO Guide 25 , others don't;

PUBLISHED LIST OF ACCREDITATION REQUIREMENTS: YES 15 NO 1 REQUIREMENTS CONSISTENT WITH GUIDE 25? YES $\underline{\underline{4}}$ NO 1 NO RESPONSE $\underline{1}$ EDITION YEAR 1990 4

GUIDANCE/INSTRUCTIONS THAT INTERPRETS/AMPLIFIES GUIDE 25 REQUIREMENTS: YES _ $\underline{5}$ NO 1 


\section{SECTIONS OF GUIDE 25 WITH ADDITIONAL GUIDANCE/INSTRUCTIONS}

4. Organization \& Mgt. .... $\frac{3}{5}$

5. System Audit/Review ..... $\frac{5}{5}$ Quality Manual/Doc. ..... $\frac{5}{(1)}$ Internal Audits ........ $\frac{(1)}{(2)}$ Corrective Actions/Doc. .

6. Personnel ........... $\frac{-4}{4}$ Training/Experience ..... $\frac{(2)}{(0)}$ Conflict of Interest Req.

7. Accommodation/Environment Laboratory Facilities ... Environmental Conditions

8. Equipment/Ref. Materials Types of Equipment ...... Equipment Labeling/Doc.

9. Traceability \& Calibration Equipment Calibration ... Measurement Traceability Standards Ref. Materials

10. Calibration/Test Methods Calibration Instructions Test Method Requirements Test Method Documentation Test Method Availability

11. Handling Calibration/Test Items

12. Records Content/Format Retention Period
13. Certificates Content/Format Modifications Client Notification

14. Subcontracting Work Eligible for Subcontracting Subcontractor Competency Requirements .......... Client Notification

15. Outside Support Services and Supplies .......... Evaluation of Quality Supplier Records

16. Complaints Doc. of Complaints Appeals Process

a. Sampling

$\begin{array}{r}1 \\ \hline \\ \hline\end{array}$


Thirty seven completed questionnaires were received. One non-U.S. response was not included because the program was being terminated.

NO. OF COMPETED QUESTIONNAIRES

31

FIELDS OF TESTING COVERED BY THE PROGRAM:

Biological 24

Chemical $\frac{27}{27}$

Ionizing Radiation 16

Electrical 24

Mechanical 26

Metrology 20

Non-destructive 20

Thermal

19

Optics and Photometry 18

Acoustic/Vibration Measurement 18

other (Specify) gas cylinders-1, applied physics-1, wool-2, medical-2,

ballistic-1, corrosion-1, EMC-2, environmental-2, fire-3, geology-1, health \& hygiene-1, information technology-2, metallurgical-1, microbiological-3, physical safety sampling-1, physico-chemical-1, fire protection-1, construction materials-3, toys-1, textiles-1, food-3, physical-1; building techniques-1; civil engineering-1; electronics and fluid flow-1, animal health-1

NUMBER OF LABORATORIES ACCREDITED: 2; 4 (10 in progress--up to 30 over next three years): $5 ; 7-2$ resp.; $11 ; 19 ; 21 ; 24 ; 37 ; 38 ; 40 ; 50 ; 52 ; 55 ;$ $56-2$ resp.; 57; 61; 72 (40 testing+32 calibration): $78 ; 114 ; 145 ; 175 ; 222 ;$ two with $350 ;>350 ; 400 ; 1446 ; 2380$

LABORATORY ACCREDITATION : Voluntary $\frac{26}{\text { Mandatory }} \frac{1}{\text { M }}$.
Other 4 participate in CGSB listing program: Mandatory in labs doing work for BNO and several ministries; Mandatory for metrology

GUIDE 25 MENTIONED IN LAW OR REGULATION? YES 13 NO 15 NO RESPONSE 1 Other 2

PUBLISHED IIST OF ACCREDITATION REQUIREMENTS?

YES

29 NO

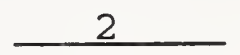

REQUIREMENTS CONSISTENT WITH GUIDE 25 YES

other 125 requirements to be confirmed in 1994

NO NR 1

EDITION YEAR 1990 24 Other 1982+1990-1;; 1994-1; 1982-2; NR-2; 1989-1

GUIDANCE/INSTRUCTIONS THAT INTERPRETS/AMPLIFIES GUIDE 25 REQUIREMENTS YES 22 NO 9 


\section{SECTIONS OF GUIDE 25 WITH ADDITIONAL GUIDANCE/INSTRUCTIONS*}

4. Organization \& Mgt. ..... 13

5. System Audit/Review ..... $\frac{13}{18}$ Quality Manual/Doc. ..... $\frac{117)}{(13)}$ Internal Audits ........ (13) Corrective Actions/Doc. . $\frac{(7)}{(13}$

6. Personnel .............. $\frac{13}{11}$ Training/Experience .... $\frac{13}{(11)}$ Conflict of Interest Req. $\frac{(11)}{(5)}$

7. Accommodation/Environment 13 Laboratory Facilities ... $\frac{13}{(10)}$ Environmental Conditions $\frac{(10)}{12}$

8. Equipment/Ref. Materials $\frac{12}{12}$ Types of Equipment ..... $\frac{1}{(8)}$ Equipment Labeling/Doc. $\frac{(8)}{(8)}$

9. Traceability \& Calibration 18 Equipment Calibration ... $\frac{(12)}{(11)}$ Measurement Traceability (11) Standards Ref. Materials $\frac{(14)}{13}$

10. Calibration/Test Methods $\frac{13}{13}$ Calibration Instructions (7) Test Method Requirements $\frac{(10)}{(10)}$ Test Method Documentation $\frac{(10)}{(7)}$ Test Method Availability (9)

11. Handling Calibration/Test Items $\ldots \ldots \ldots \ldots \ldots$

12. Records .............. $\frac{13}{13}$ Content/Format .............. $\frac{1}{(10)}$ Retention Period ....... $\frac{(10)}{15}$

13. Certificates ........... $\frac{15}{15}$

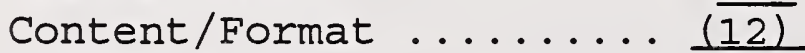
Modifications ............ $\frac{(12)}{(9)}$ Client Notification ..... (
14. Subcontracting ........ 12 Work Eligible for

Subcontracting ........ (9)

Subcontractor Competency Requirements .......

Client Notification ....

15. Outside Support Services and Supplies ......... Evaluation of Quality ... $\frac{(6)}{(6)}$ Supplier Records ...... $\frac{(5)}{(5)}$

16. Complaints ........... 10 Doc. of Complaints ..... $\frac{1}{(5)}$ Appeals Process ........ (3)

\section{OTHER}

a. Sampling ........... 9

b. Laboratory Safety ..... $\frac{5}{5}$

c. Site Testing .......... $\frac{12}{12}$

(Specify Additional Requirements)

d. Signatory requirements . 2

e. Accreditation body endorsed test reports ...........

f. Subcontracting by accred. lab only.............. 1

g. inspection of cert prog. 1

h. additional req. for calibration labs ........1

i Verification practices ...

$j$ Confidentiality and proprietary rights....... 1

Availability of Documents in English - Yes $\frac{18 *}{\text { No }} 7 * \star$
COMMENTS $\star$ By end of year; $\star 1 / 2$ in English; $\star \star t$ translation in progress; $\star *$ some translated; $* * *$ not for metrology, but for others 


\section{APPENDIX X \\ RELATED INFORMATION AND PUBLICATIONS \\ AVAILABLE FROM \\ Standards Code and Information Program (SCI) \\ office of Standards Services \\ National Institute of Standards and Technology}

- The ABC's of Standards-Related Activities in the United States (NBSIR $87-3576)$

This report is an introduction to voluntary standardization, product certification and laboratory accreditation for readers not fully familiar with these topics. It stresses some of the more important aspects of these fields; furnishes the reader with both historical and current information on these topics; describes the importance and impact of the development and use of standards; and serves as background for using available documents and services. Order as PB 87-224309 from NTIS.

- The $A B C^{\prime} S$ of Certification Activities in the United states

(NBSIR 88-3821)

This report, a sequel to NBSIR 87-3576, The ABC'S of standards-Related Activities in the United States, provides an introduction to certification for readers not entirely familiar with this topic. It highlights some of the more important aspects of this field, furnishes the reader with information necessary to make informed purchases, and serves as background for using available documents and services. Order as PB 88-239793 from NTIS.

\section{- Laboratory Accreditation in the United States (NISTIR 4576)}

This report, a sequel to NBSIR 87-3576 The ABC'S of standards-Related Activities in the United states and NBSIR 88-3821 The ABC'S of Certification Activities in the United States, is designed to provide information on laboratory accreditation to readers who are new to this field. It discusses some of the more significant facets of this topic, provides information necessary to make informed decisions on the selection and use of laboratories, and serves as background for using other available documents and services. Order as PB 91-194495 from NTIS.

- Questions and Answers on Quality, the ISO 9000 standard Series, Quality System Registration, and Related Issues (NISTIR 4721)

This report provides information on the development, content and application of the ISO 9000 standards to readers who are unfamiliar with these aspects of the standards. It attempts to answer some of the most commonly asked questions on quality; quality systems; the content, application and revision of the ISO 9000 standards; quality system approval/registration; European Community requirements for quality system approval/registration; and sources for additional help.

Copies not available from SCI. Order as PB 93-152080/AS from NTIS.

- More Questions and Answers on the ISO 9000 standard Series and Related Issues (NISTIR 5122)

This report, a sequel to NISTIR 4721, provides additional information on the ISO 9000 standards and related issues to readers unfamiliar with some of the new developments in this area. It attempts to answer additional questions on ISO 9000 standards related issues which NIST has received since the publication of NISTIR 4721. It also identifies sources for further help in this area. Copies not available from SCI. Order as PB 93-140689 from NTIS. 
This directory contains information on 338 international and regional organizations which conduct standardization, certification, laboratory accreditation, or other standards-related activities. It describes their work in these areas, as well as the scope of each organization, national affiliations of members, U.S. participants, restrictions on membership, and the availability of any standards in English.

Copies not available from SCI. Order as PB 89-221147 from NTIS or order as Cat. \#SP767 from Global Engineering Documents.

- Directory of European Regional Standards-Related Organizations (NIST SP 795)

This directory identifies more than 150 European regional organizations both governmental and private - that engage in standards development, certification, laboratory accreditation and other standards-related activities, such as quality assurance. Entries describe the type and purpose of each organization; acronyms; national affiliations of members; the nature of the standards-related activity; and other related information.

Copies not available from SCI. Order as PB 91-107599 from NTIS or order as Cat. \#0258-3 from Global Engineering Documents.

\section{- Standards Activities of Organizations in the United States}

(NIST SP 806)

The directory identifies and describes activities of over 750 U.S. public and private sector organizations which develop, publish, and revise standards; participate in this process; or identify standards and make them available through information centers or distribution channels. NIST SP 806 , a revision of NBS SP 681, covers activities related to both mandatory and voluntary U.S. standards. SP 806 also contains a subject index and related listings that cover acronyms and initials, defunct bodies and organizations with name changes. Copies not available from SCI. Order as PB 91-177774 from NTIS or order as Cat. \#SP806 from Global Engineering Documents.

\section{- Directory of Private Sector Product Certification Programs \\ (NIST SP 774)}

This directory presents information from 132 private sector organizations in the United States which engage in product certification activities. Entries describe the type and purpose of each organization, the nature of the activity, product certified, standards used, certification requirements, availability and cost of services, and other relevant details. Copies not available from SCI. Order as PB 90-161712 from NTIS.

\section{- Directory of Federal Government Certification Programs}

(NBS SP 739)

This directory presents information on U.S. Government certification programs for products and services. Entries describe the scope and nature of each certification program, testing and inspection practices, standards used, methods of identification and enforcement, reciprocal recognition or acceptance of certification, and other relevant details. Copies not available from SCI. Order as PB 88-201512 from NTIS. 
- Directory of Federal Government Laboratory Accreditation/ Designation Programs (NIST SP 808)

This directory provides updated information on 31 federal government laboratory accreditation and similar type programs conducted by the federal government. These programs, which include some type of assessment regarding laboratory capability, designate sets of laboratories or other entities to conduct testing to assist federal agencies in carrying out their responsibilities. The directory also lists 13 other federal agency programs of possible interest, including programs involving very limited laboratory assessment and programs still under development. Copies not available from SCI. Order as PB 91-167379 from NTIS.

- Directory of State and Local Government Laboratory Accreditation/ Designation Programs (NIST SP 815)

This directory provides updated information on 21 state and 11 local government laboratory accreditation and similar type programs. These programs, which include some type of assessment regarding laboratory capability, designate private sector laboratories or other entities to conduct testing to assist state and local government agencies in carrying out their responsibilities. Entries describe the scope and nature of each program, laboratory assessment criteria and procedures used in the program, products and fields of testing covered, program authority, and other relevant details. Copies not available from SCI. Order as PB 92-108968 from NTIS.

- Directory of Professional/Trade organization Laboratory Accreditation/Designation Programs (NIST SP 831)

This directory is a guide to laboratory accreditation and similar types of programs conducted by professional and trade organizations. These programs accredit or designate laboratories or other entities to assist private sector professional societies, trade associations, related certification bodies, their membership, as well as government agencies, in carrying out their responsibilities. This accreditation or designation is based on an assessment of the capability of the laboratory to conduct the testing. However, the nature of the assessment varies considerably by organization and program. Order as SN 003-003-03144-5 from GPO.

- Barriers Encountered by U.S. Exporters of Telecommunications Equipment (NBSIR 87-3641)

This report addresses the perceived institution of unreasonable technical trade barriers by major European trading partners to the export of telecom products and systems by U.S. companies. The GATT technical office, which has responsibilities to assist U.S. exporters to take advantage of trade opportunities, informally contacted over a period of six months, telecom companies and agencies to assess the extent of unreasonableness in non-U.S. national standards, regulations, testing and certification requirements, and accreditation procedures. Copies not available from SCI. Order as PB 88153630 from NTIS.

- A Review of U.S. Participation in International Standards Activities (NBSIR $88-3698$ )

This report describes the role of international standards, their increasingly significant importance in world trade, and the extent of past and current U.S. participation in the two major international standardization bodies - ISO and IEC. The degree of U.S. participation covers the 20 year period 1966-1986. A coarse analysis of data indicates some correlation between U.S. participation and recent export performance for several major product categories. Copies not available from SCI. Order as PB 88-164165 from NTIS. 
- An Update of U.S. Participation in International Standards Activities

(NISTIR 89-4124)

This report presents updated information on the current level

of U.S. participation in ISO and IEC (reference: NBSIR 88-3698).

Copies not available from SCI. Order as PB 89-228282/AS from NTIS.

- A Summary of the New European Community Approach to standards Development (NBSIR 88-3793-1)

This paper summarizes European Community (EC) plans to aggressively pursue its goal of achieving an "internal market" by 1992 and the standards-related implications of such a program on U.S. exporters. Order as PB 88-229489/AS from NTIS.

- Trade Implications of Processes and Production Methods (PPMS) (NISTIR 904265 )

This report discusses processes and production methods (or PPMs) and their relationship to trade, the GATT Agreement on Technical Barriers to Trade, and traditional product standards used in international commerce. The report provides background information on PPM's, a suggested definition, and the possible extension of their application from the agricultural sector to industrial products. Order as PB 90-205485 from NTIS.

\section{The following documents are available upon request from SCI.}

\section{- tbt news}

This newsletter provides information on government programs and available services established in support of the GATT Agreement on Technical Barriers to Trade (Standards Code). tbt news reports on the latest notifications of proposed foreign regulations; bilateral consultations with major U.S. trade partners; programs of interest to U.S. exporters; and availability of standards and certification information. Subscription is free upon request.

\section{- Technical Barriers to Trade}

This booklet explains the basic rules of the international Agreement on Technical Barriers to Trade negotiated during the Tokyo Round of the Multilateral Trade Negotiations (MTN), and describes Title IV of the U.S. Trade Agreements Act of 1979 which implements the United States' obligations under the Agreement.

The Agreement, popularly known as the Standards Code, was designed to eliminate the use of standards and certification systems as barriers to trade. The booklet describes the functions of the Departments of Commerce and Agriculture, the Office of the U.S. Trade Representative, and the State Department in carrying out the U.S.'s responsibilities.

\section{- "GATT Standards Code Activities"}

This brochure gives a brief description of NIST's activities in support of the Standards Code. These activities include operating the U.S. GATT inquiry point for information on standards and certification systems; notifying the GATT Secretariat of proposed U.S. regulations; assisting U.S. industry with trade-related standards problems; responding to inquiries on foreign and U.S. proposed regulations; and preparing reports on the standard Code. 
- GATT Standards Code Activities of the National Institute of standards and Technology

This annual report describes the GATT Standards code activities conducted by the standards Code and Information Program for each calendar year. NIST responsibilities include operating the GATT inquiry point, notifying the GATT Secretariat of proposed U.S. Federal government regulations which may affect trade, assisting U.S. industry with standards-related trade problems, and responding to inquiries about proposed foreign and U.S. regulations.

- Free handout material on office activities and standards-related information such as: government sources of specifications and standards; foreign standards bodies; U.S. standards organizations; and a brochure on the National Center for Standards and Certification Information (NCSCI).

In addition to general inquiry services, the following assistance is also available:

- EC Hotline

This hotline reports on draft standards of the European Committee on Standardization (CEN), the European Committee for Electrotechnical Standardization (CENELEC) and the European Telecommunications Standards Institute (ETSI). It also provides information on selected EC directives. The recorded message is updated weekly and gives the product, document number and closing date for comments. The hotline number is (301) 921-4164 (not tollfree).

- GATT Hotline

A telephone hotline provides current information received from the GATT Secretariat in Geneva, Switzerland, on proposed foreign regulations which may significantly affect trade. The recorded message is updated weekly and gives the product, country, closing date for comments (if any) and Technical Barriers to Trade notification (TBT/Notif.) number. The hotline number is (301) $975-4041$ (not toll-free).

- NCSCI provides assistance to U.S. and foreign exporters in obtaining current standards, regulations and certification information for the manufacture of products. To aid foreign exporters, NCSCI also provides directory information of state offices prepared to respond to queries concerning conditions to be met by goods for sale in their state. 


\section{Contacts:}

National Technical Information Service (NTIS) 5285 Port Royal Road

Springfield, Virginia 22161, USA

Phone:

(703) 487-4650

Orders Only: (800) 553-6847

Fax:

(703) 321-8547

Superintendent of Documents

U.S. Government Printing Office (GPO)

Washington, DC 20402, USA

$\begin{array}{ll}\text { Phone: } & (202) 783-3238 \\ \text { Fax: } & (202) 512-2250\end{array}$

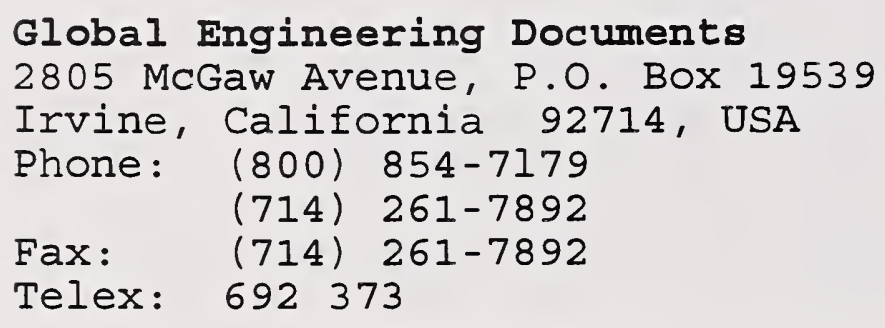

When requesting information from SCI, please send a self-addressed mailing label to:

Standards Code and Information Program (SCI)

National Institute of Standards and Technology

Administration Building, Room A629

Gaithersburg, Maryland 20899, USA

For further information, call (301) 975-4029 


